Islamic Republic of Iran: 2011 Article IV Consultation-Staff Report; Public Information Notice on the Executive Board Discussion; and Statement by the Executive Director for Iran

Under Article IV of the IMF's Articles of Agreement, the IMF holds bilateral discussions with members, usually every year. In the context of the 2011 Article IV consultation with the Islamic Republic of Iran, the following documents have been released and are included in this package:

- The staff report for the 2011 Article IV consultation, prepared by a staff team of the IMF, following discussions that ended on June 9, 2011, with the officials of the Islamic Republic of Iran on economic developments and policies. Based on information available at the time of these discussions, the staff report was completed on July 5, 2011. The views expressed in the staff report are those of the staff team and do not necessarily reflect the views of the Executive Board of the IMF.

- $\quad$ A Public Information Notice (PIN) summarizing the views of the Executive Board as expressed during its July 20, 2011 discussion of the staff report that concluded the Article IV consultation.

- $\quad$ A statement by the Executive Director for the Islamic Republic of Iran.

The document listed below has been or will be separately released.

\title{
Selected Issues Paper
}

The policy of publication of staff reports and other documents allows for the deletion of market-sensitive information.

\author{
Copies of this report are available to the public from \\ International Monetary Fund • Publication Services \\ $70019^{\text {th }}$ Street, N.W. $\bullet$ Washington, D.C. 20431 \\ Telephone: (202) 623-7430 • Telefax: (202) 623-7201 \\ E-mail: publications@imf.org Internet: http://www.imf.org
}

\section{International Monetary Fund Washington, D.C.}




\title{
INTERNATIONAL MONETARY FUND
}

\author{
ISLAMIC REPUBLIC OF IRAN \\ Staff Report for the 2011 Article IV Consultation \\ Prepared by the Staff Representatives for the 2011 Consultation with \\ the Islamic Republic of Iran \\ Approved by Ratna Sahay and David D. Marston
}

July 5, 2011

Discussions: Held in Tehran May 28-June 9, 2011. The mission met with

H.E. Seyyed Shamseddin Hosseini, Minister of Economic Affairs and Finance;

H.E. Dr. Mahmoud Bahmani, Governor of the Central Bank and other representatives from the public and private sectors and academics. A press release issued at the conclusion of the discussions can be found at: http://www.imf.org/external/np/sec/pr/2011/pr11228.htm

Staff Team: The mission comprised Mr. Dominique Guillaume (Head), Messrs. Ozgur Demirkol, Gabriel Sensenbrenner, Roman Zytek, (all MCD) and Ms. Majdeline El Rayess (STA). Mr. Jafar Mojarrad (OED) participated in policy discussions.

Exchange Arrangement: The Islamic Republic of Iran maintains a de jure managed floating arrangement against a basket of currencies. With effect from September 6, 2004, the Islamic Republic of Iran accepted the obligations under Article VIII, Sections 2, 3, and 4 of the Fund's Articles of Agreement. Iran maintains one exchange restriction and one multiple currency practice subject to Fund jurisdiction under Article VIII, Sections 2(a) and 3 (see Informational Annex).

Past Surveillance: The 2009 Article IV Consultation was concluded on Feb 3, 2010. The Public Information Notice of the Executive Board's discussion is available at http://www.imf.org/external/np/sec/pn/2010/pn1024.htm

Statistics: Data is broadly adequate for surveillance: The authorities have indicated their interest in participating in the General Data Dissemination Standard (GDDS). 


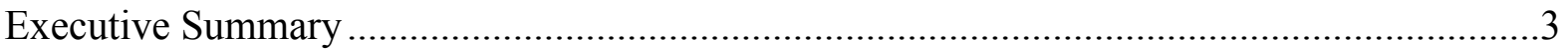

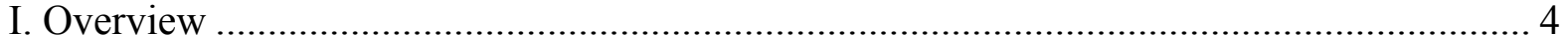

II. Recent Economic Developments and Outlook............................................................. 5

A. Recent Economic Developments .......................................................................... 5

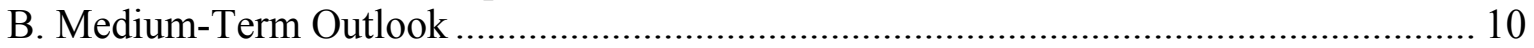

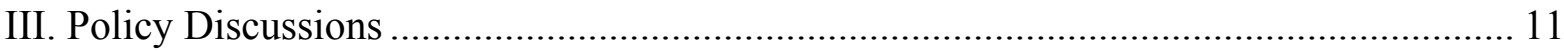

A. Preserving Macroeconomic Stability in the Near Term............................................ 11

B. Ensuring the Transition to a Market-Based Economy to Foster Growth

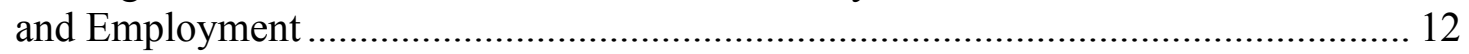

C. Strengthening the Financial Sector to Sustain Economic Development...................... 16

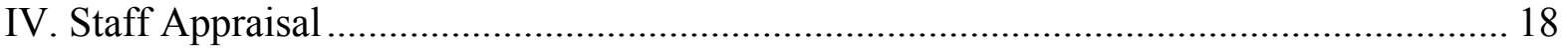

\section{Text Table}

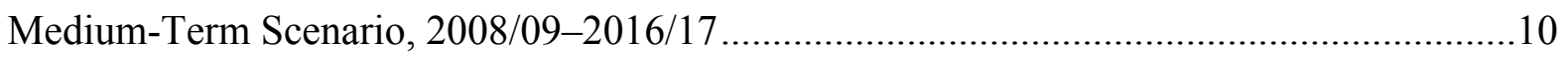

Boxes

1. Initial Impact of the Targeted Subsidy Reform .................................................4

2. Is there a Price Bubble in the Tehran Stock Exchange? ..........................................

Figures

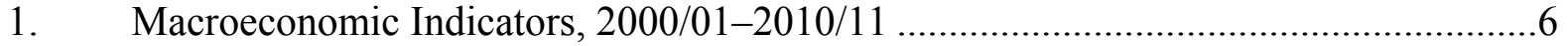

2. Macroeconomic and Price Developments, 2005/06-2010/11 ................................. 7

3. Distribution of Oil Revenue for 2011/12 ..........................................................

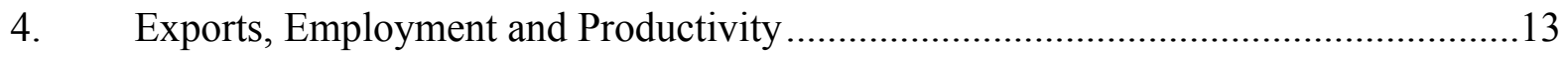

5. Demographics, Labor Market and Business Environment ......................................14

Tables

1. Selected Macroeconomic Indicators, 2007/08-2011/12 _........................................21

2. Balance of Payments, 2007/08-2016/17 ..........................................................22

3a. Statement of Government Operations 2007/08-2011/12 (in billions of Rials) ...........23

3b. Financial Balance Sheet 2008/09-2010/11 ..............................................................24

4. Statement of Government Operations 2007/08-2011/12 .......................................25

5. Central Bank Balance Sheet, 2007/08-2011/12 …................................................26

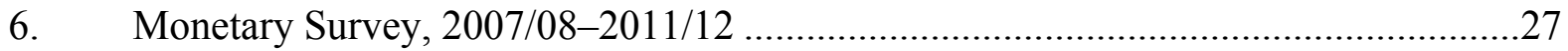

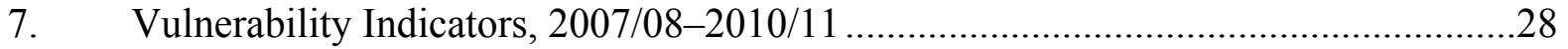

Appendices

I. Exchange Rate Assessment..............................................................................29

II. Migration of Iran Fiscal Presentation into the GFSM 2001 Presentation....................31 


\section{Executive Summary}

Background and outlook: Growth recovered on the strength of international oil prices, strong rebound in agricultural sector and rapid credit expansion. Inflation was contained while fiscal and external positions improved. The launch of the subsidy reform in December 2010 has increased inflation temporarily and is expected to result in a temporary slowdown of economic growth. While high oil prices and efficiency gains resulting from the subsidy reform should support rapid economic recovery, an accommodative policy stance could lead to high inflation and derail reform efforts.

Policies priorities: Key priorities are to (i) maintain short term macroeconomic stability to support the reform process; (ii) transition further to a market-based economy to foster growth and support job creation; and, (iii) strengthen the financial sector.

\section{Staff Recommendations:}

- $\quad$ Coordinated and tight credit and fiscal policies are essential to maintain macroeconomic stability in the aftermath of the subsidy reform.

- $\quad$ The authorities should continue to flexibly manage the exchange rate, and maintain a unified exchange rate.

- $\quad$ Achieving higher growth and creating new jobs will require restructuring the corporate sector, supporting the creation of new enterprises, removing labor market frictions, encouraging foreign investment, and accelerating the ongoing privatization process.

- $\quad$ Addressing the banking sector's large NPLs portfolio, and strengthening capital adequacy and profitability are essential to allow the banking sector to support growth.

\section{Authorities' Views:}

- $\quad$ Steadfast implementation of the subsidy reform will continue, while preserving macroeconomic stability in the transition period, including through limiting central bank credit to banks and possible increasing interest rates.

- $\quad$ Corporate restructuring might require more subsidized loans and financing.

- $\quad$ Recapitalizing public banks, further reducing NPLs, enhancing central bank supervision, and introducing a deposit guarantee fund are important elements of the banking reform strategy. 


\section{OVERVIEW}

1. Iran is benefitting from the rebound in international oil prices. With the breakeven price for the budget and current account in 2010/11 at $\$ 75$ per barrel and $\$ 60$ per barrel respectively, the increase in oil price to $\$ 80$ per barrel on average, has helped improve the current account and budget surplus, and maintain comfortable international reserves.

\section{The sharp increase in the domestic prices of energy products on December 19,} 2010 is estimated to have reduced the cost of subsidies by about 15 percent of GDP (US\$60 billion) ${ }^{1}$ Equal cash transfers to 70 million people were made ahead of the price increase. The early stage of implementation of the reform was largely positive (Box 1).

\section{Box 1. Initial Impact of the Targeted Subsidy Reform ${ }^{1 /}$}

The subsidy reform law stipulates that out of the revenue arising from the price increase, about US\$30 billion is to be redistributed in the first year to households in freely usable cash, $\$ 15-18$ billion to enterprises to finance their restructuring to reduce energy intensity, and around $\$ 10-12$ billion to the government to allow it to pay for higher energy bills and improve energy efficiency in the public sector.

The distribution of cash transfers to households is estimated to have reduced poverty incidence from 12 to 2 percent, on the basis of a $\$ 2$ per day poverty line. Moreover, regional disparities in poverty have sharply declined. The distribution of cash transfers markedly improved income distribution. As a result, the Gini coefficient is estimated to have fallen from $0.40-0.45$ before the reform to 0.37 after the implementation of the subsidy reform.

Energy consumption reportedly declined by up to 20 percent for some fuels. The impact on the environment is estimated to be positive. Preliminary estimates show a reduction in most emissions from fossil fuels.

\begin{tabular}{|c|c|}
\hline GHG Component & Percentage Reduction \\
\hline $\mathrm{NO}_{\mathrm{x}}$ & $10-15$ \\
\hline $\mathrm{SO}_{2}$ & $14-20$ \\
\hline $\mathrm{CO}_{2}$ & $8-15$ \\
\hline $\mathrm{SO}_{3}$ & $15-22$ \\
\hline $\mathrm{SPM}$ & $2-16$ \\
\hline
\end{tabular}

1/ For a full account of the early implementation of the reform, see Guillaume and Zytek, "The Chronicles of the Subsidy Reform," IMF Working Paper (forthcoming).

3. New international sanctions in $\mathbf{2 0 1 0}$ have in practice increased the cost of doing business, limited FDI and technology transfer, and have affected international trade and financial transactions. The United Nations Security Council (UNSC) sanctions include a ban on financing and exports related to Iran's nuclear and military programs. Additional

\footnotetext{
${ }^{1}$ Most energy prices were raised to about half of their international price level at the time of the reform. Prices of fuel oil, kerosene, and diesel were raised from about 1 to 1.6 cents per liter to 10 to 35 cents a liter. Gasoline prices went up from 10/15 cents per liter (regular/premium) to 70/80 cents per liter for un-rationed quantities (40/55 cents for up to 60 liters per car per month). Multi-tier, escalating electricity (natural gas) tariffs rose from an average of about 1.5 cents per KWh (cubic meter) to 5-7 cents per unit. Wheat prices were raised more than 40 times and bread prices were allowed to increase gradually.
} 
sanctions beyond those called for by the UNSC pose constraints on some international financial transactions, particularly in the Euro and the U.S. dollar. The authorities have expressed concern over these sanctions and those imposed by the UNSC and their effect on Iran's ability to participate, in particular, in payments and settlements under the international monetary system.

\section{RECENT ECONOMIC DEVELOPMENTS AND OUTLOOK}

\section{A. Recent Economic Developments}

4. Economic growth accelerated from the cyclical downturn in 2008/09 (Figure 1). A severe drought and cuts in oil production slowed growth to 0.6 percent in 2008/09. However, a sharp rebound in agriculture production supported modest economic recovery in $2009 / 10$ and further expansion in 2010/11. The distribution of cash transfers to households is estimated to have partly offset the negative impact of the energy price increases on domestic demand, resulting in a moderate decline of real GDP growth from 3.5 percent in 2009/10 to 3.2 percent 2010/11. On the strength of high oil prices, the current account surplus improved to 6 percent of GDP in 2010/11.

\section{Building upon their success in reducing inflation over the last few years, the authorities were able to contain inflation in the aftermath of the subsidy reform} (Figure 2). The authorities' monetary policy implementation brought down annual average inflation from 25.4 percent in 2008/09 to 12.4 percent in 2010/11. Despite the very large domestic energy price increases in December, inflation remained relatively contained. Numerous administrative measures, such as price monitoring and enforcement of price transparency and the accumulation of inventories of strategic foodstuffs, helped slow down the pass-through of higher energy prices into other prices. While there was an almost doubling of the central bank's claims on banks (related mainly to the financing of subsidized housing), the central bank sterilized this increase by selling foreign exchange. As a result, consumer price inflation only increased from 10.1 percent in December to 14.2 percent at end-May 2011, with the average monthly inflation rate for January-May reaching only $2 \frac{1}{4}$ percent.

6. The fiscal surplus improved in 2010/11 to 1.7 percent of GDP, reflecting prudent spending policies. In particular, the authorities reduced capital spending, and saved some of the extra revenue from increased oil prices in the newly established National Development Fund (NDF) (Figure 3). ${ }^{2}$

\footnotetext{
${ }^{2}$ Borrowing from the NDF by the government is not allowed. The Oil Stabilization Fund (OSF) will continue to exist as a separate government account.
} 
Figure 1. Iran: Macroeconomic Indicators, 2000/01-2010/11
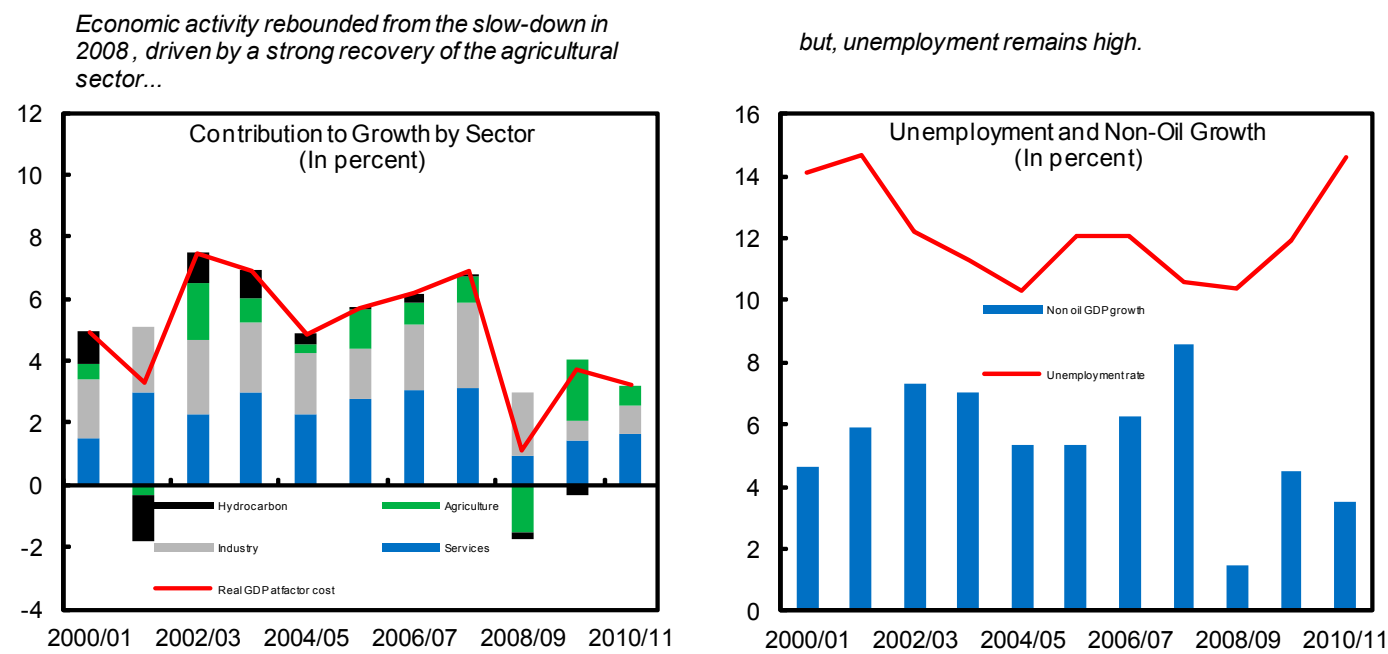

Non-oil fiscal balance improved, reflecting better nonoil revenue performance and prudent spending over the past few years ...

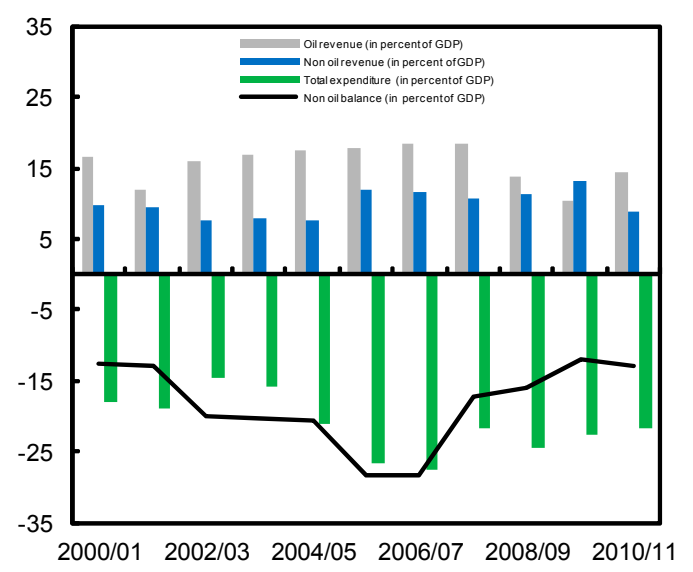

Reserves remained at a comfortable level while current account followed changes in oil prices

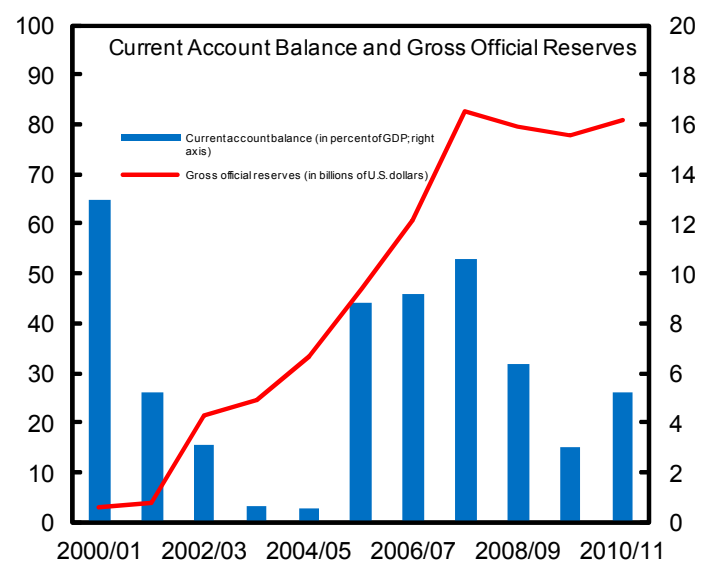

Low and declining external debt reflects current account surpluses as well as international sanctions ...

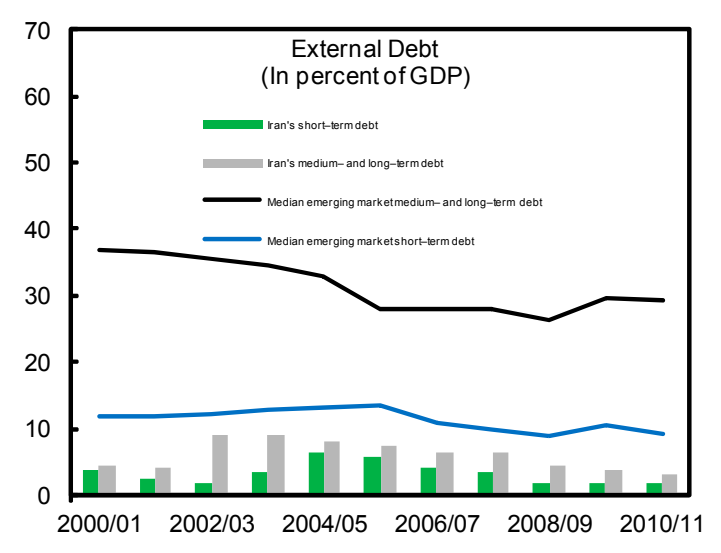

The stock market has outperformed the region largely reflecting IPOs.

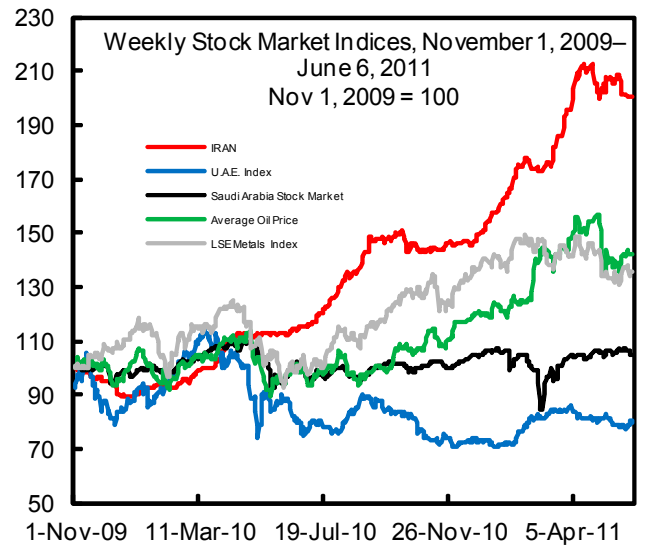

Source: Iranian authorities; and Fund staff estimates. 
Figure 2. Iran: Macroeconomic and Price Developments, 2005/06-2010/11
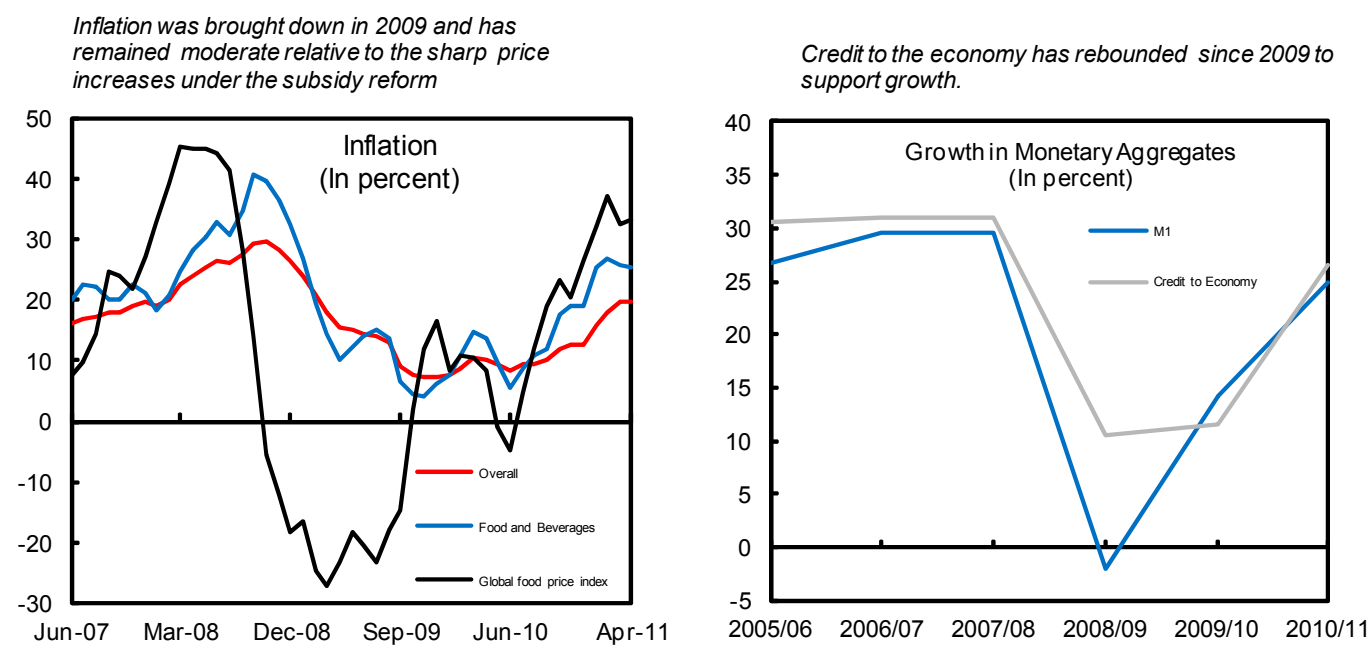

Real interest rates turned negative in late 2010 fuelling appetite for other investments....
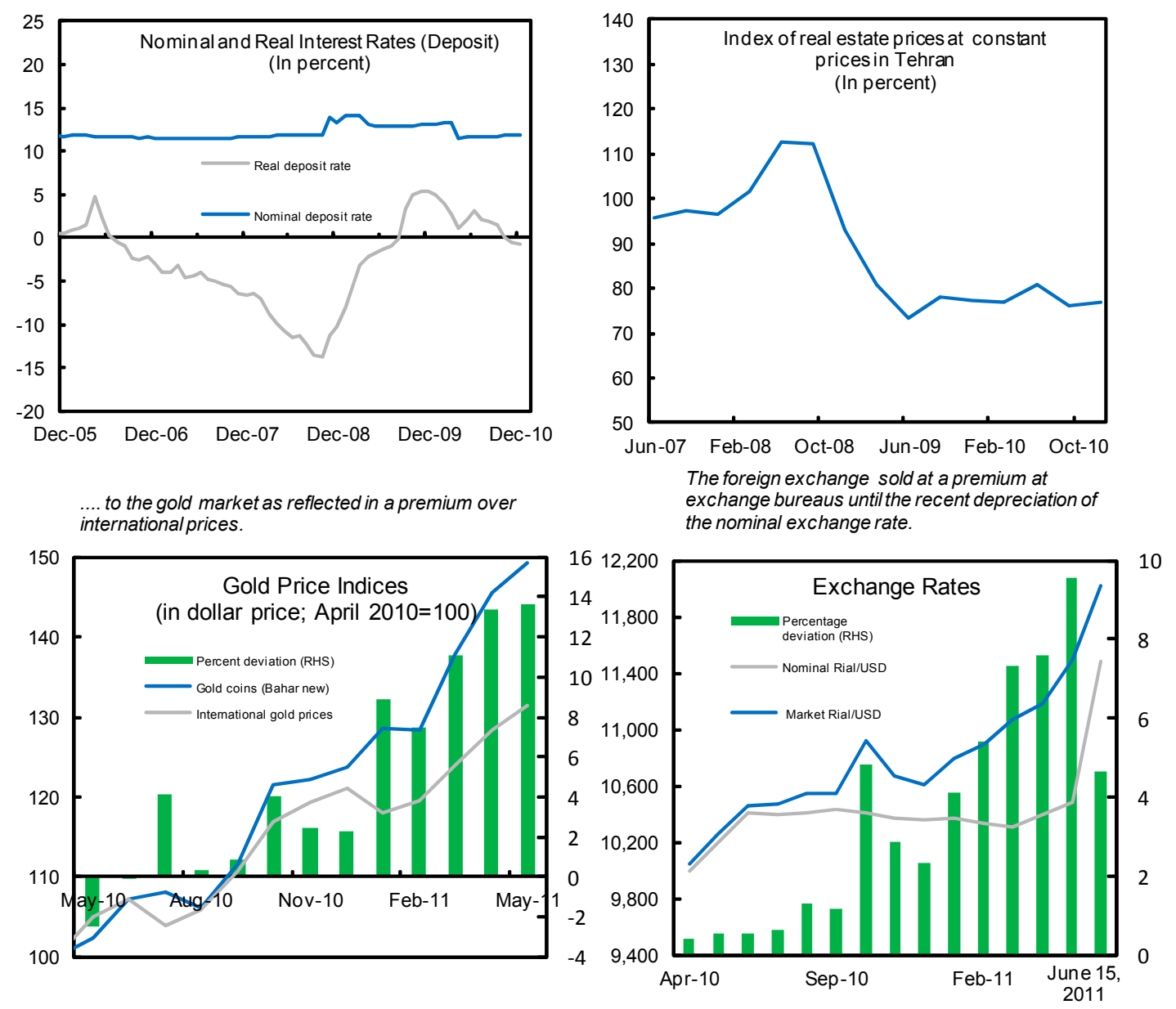

Source: Iranian authorities; and Fund staff estimates. 
7. To address a widening spread between the interbank and parallel exchange rates, the central bank allowed the rial to depreciate by 11.5 percent on June 8

(Figure 2). While overall money growth remained moderate, the increase in central bank credit to banks led to the emergence of a spread between the interbank rate and the "parallel" rate offered at exchange bureaus, as well as to a rapid increase in gold coin prices (Figure 2). The increase in the use of exchange bureaus also reflected the impact of sanctions on the conduct of international financial transactions through the banking system. ${ }^{3}$

8. The financial sector has undergone major transformations in the last two years. Four public banks were privatized and listed on the Tehran Stock Exchange (TSE), making private banks the largest segment in the market. About 1,700 credit cooperatives were brought under the central bank's supervision. Nonperforming loans (NPLs) stood at 13.5 percent of total loan portfolio at the end of March 2011 down from 24.5 percent in January 2010, reflecting intensified loan collection efforts. At the same time, capital adequacy ratios declined from 9.6 percent in March 2010 to 8.4 percent at the end of March 2011 , reflecting increasing capitalization needs of public banks. While the surge of equity prices since 2009 has been large, staff analysis suggests that stock prices have not yet reached bubble levels, with supportive fundamental factors, including high levels of IPOs, having been at play (Box 2).

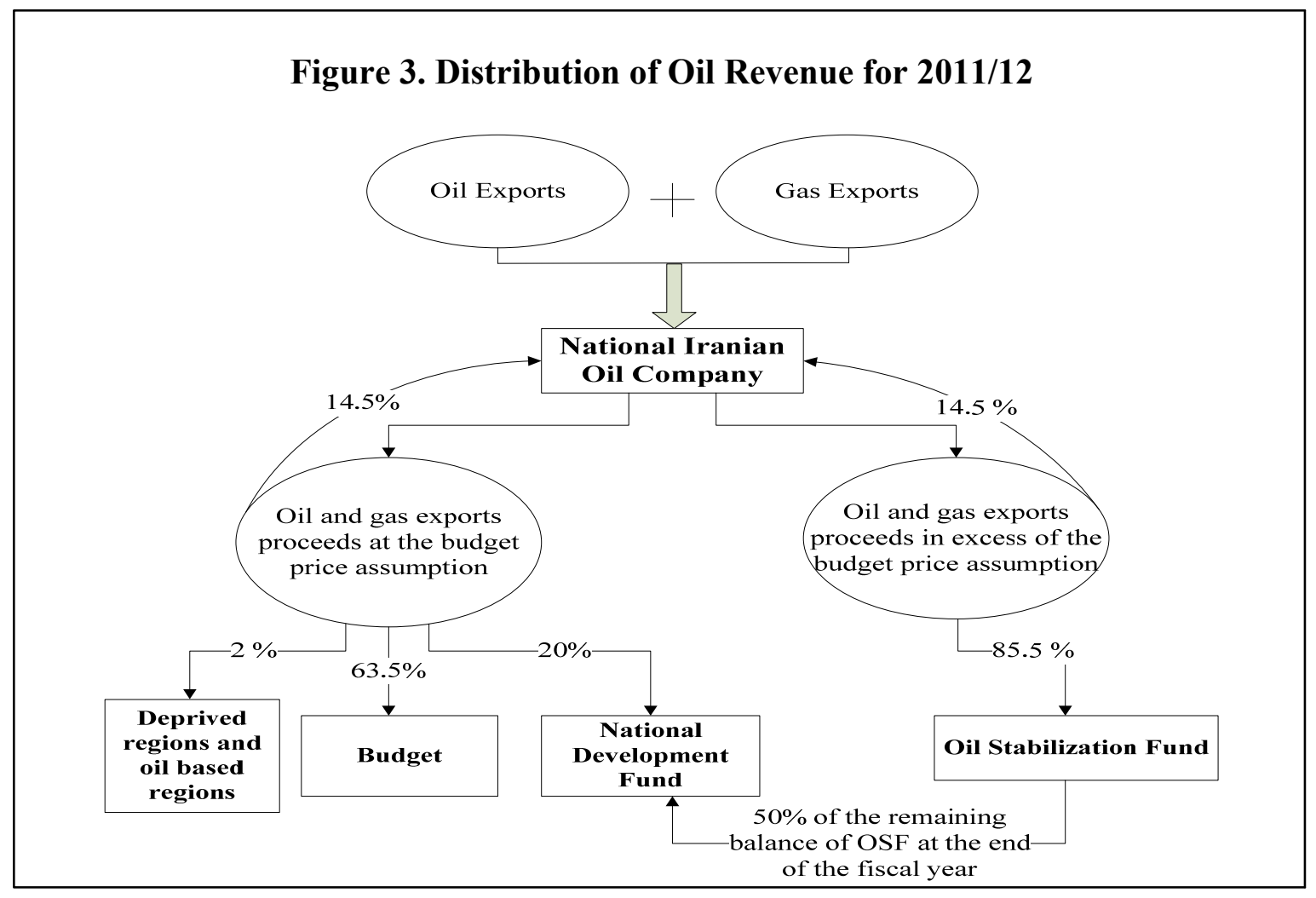

\footnotetext{
${ }^{3}$ The authorities have reported that they are actively monitoring transactions at the exchange bureaus and are cracking down on the bureaus that conduct transactions at exchange rates that differ from the interbank market exchange rate. Staff will continue to monitor this issue, and does not see this time elements pointing to the existence of a multiple currency practice in connection with the spread between the interbank rate and the parallel rate at the exchange bureaus.
} 


\section{Box 2. Is there a Price Bubble in the Tehran Stock Exchange?}

By April 2011, the Tehran Stock Exchange (TSE) all-share index (TEPIX) had increased 200 percent from its early 2009 low, raising concerns about a bubble. Russia and Turkey had comparable increases in the region. The TEPIX growth was broad-based across sectors. It coincided with a surge in IPOs related to Iran's privatization program, which allows for 80 percent of state assets to be sold: 40 percent via the distribution of shares to low-income households; 40 percent via IPOs. The increase in free float has encouraged trading and developed a shareholding culture, an explicit objective of the government. The decline in real estate prices and the low real deposit rates have also contributed to increasing the attractiveness of equities as an investment.

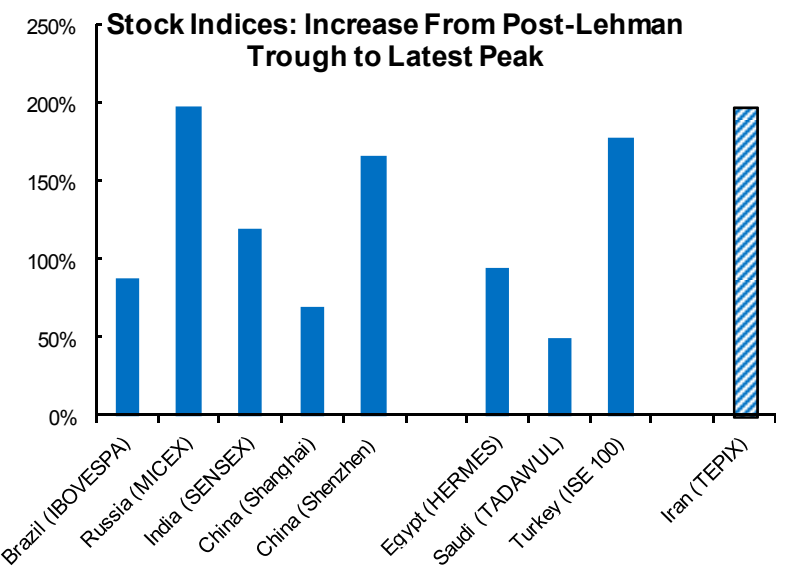

Although the price surge between early 2009 and April 2011 has been the largest in any 2-year window over the past ten years, the TSE is not an outlier. China, Egypt, and Saudi Arabia have had price surges up to twice as large as Iran during that period of time. Moreover, Iran's episodes of stock market corrections since 2001 have been the smallest among the comparator countries considered here.
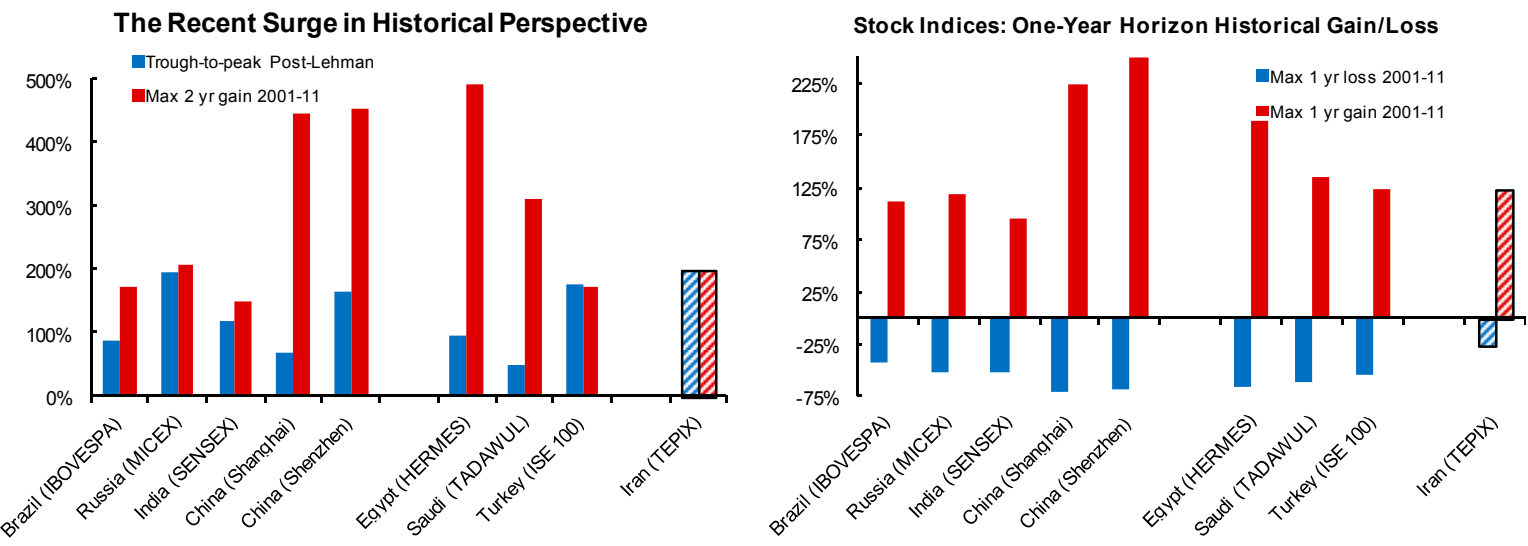

There is also no evidence of a bubble from looking at valuations. Compared with other markets where price/earnings ratios (P/Es) have been in excess of 10, TSE P/Es remain low at around 6, partly reflecting Iran's frontier market status and international sanctions.
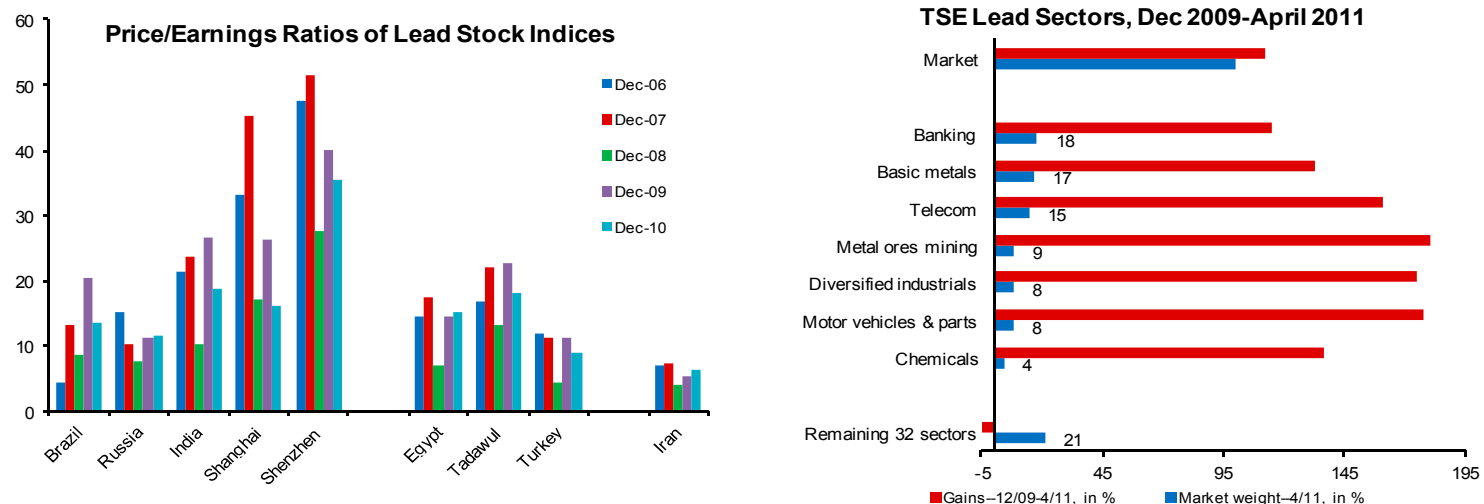


\section{B. Medium-Term Outlook}

9. With prudent macroeconomic policies, the medium-term outlook is positive.

On the strength of high oil prices and expected efficiency gains resulting from the domestic subsidy reform, growth is expected to rebound to about 4.5 percent in the medium term (Text Table 1). Moreover, compensatory payments to households and limited import substitution because of sanctions and higher tariffs on consumption goods, should help mitigate the immediate negative impact of the subsidy reform on growth. Average inflation is expected to rise to about 23 percent in 2011/12 because of the step increases in the price level, but should come down to 12 percent in 2012/13 if the authorities maintain tight macroeconomic policies. The current account surplus is projected to rise in line with the increase in oil prices to reach about 9 percent of GDP in 2011/12.

Text Table 1. Islamic Republic of Iran: Medium-Term Scenario, 2008/09-2016/17 1/

\begin{tabular}{|c|c|c|c|c|c|c|c|c|c|}
\hline & \multirow[b]{2}{*}{$2008 / 09$} & \multirow[b]{2}{*}{$2009 / 10$} & \multicolumn{3}{|l|}{ Est. } & \multicolumn{2}{|c|}{ Projection } & \multirow[b]{2}{*}{$2015 / 16$} & \multirow[b]{2}{*}{$2016 / 17$} \\
\hline & & & $2010 / 11$ & $2011 / 12$ & $2012 / 13$ & $2013 / 14$ & $2014 / 15$ & & \\
\hline & \multicolumn{9}{|c|}{ (Annual percentage change) } \\
\hline Real GDP at market prices & 0.6 & 3.5 & 3.2 & 2.5 & 3.4 & 3.8 & 4.5 & 4.6 & 4.6 \\
\hline \multirow[t]{2}{*}{ CPI inflation (average) } & 25.4 & 10.8 & 12.4 & 22.5 & 12.5 & 10.0 & 8.0 & 7.0 & 7.0 \\
\hline & \multicolumn{9}{|c|}{ (In percent of GDP; unless otherwise indicated) } \\
\hline Overall government balance & 0.7 & 1.0 & 1.7 & 2.8 & 1.3 & 1.0 & 0.8 & 0.5 & 0.4 \\
\hline Non-oil balance in percent of non-oil GDP & -26.2 & -15.2 & -16.6 & -16.9 & -16.6 & -15.7 & -15.0 & -14.4 & -13.6 \\
\hline External current account balance & 6.5 & 3.0 & 6.0 & 8.7 & 8.2 & 7.5 & 7.0 & 6.8 & 6.5 \\
\hline Investment & 37.4 & 37.4 & 37.6 & 42.6 & 41.1 & 40.2 & 39.4 & 38.4 & 37.5 \\
\hline Change in stocks & 9.0 & 11.1 & 11.8 & 15.0 & 14.3 & 13.7 & 12.9 & 12.3 & 11.6 \\
\hline Total fixed capital investment & 28.4 & 26.3 & 25.8 & 27.6 & 26.8 & 26.6 & 26.4 & 26.2 & 25.9 \\
\hline Public & 9.3 & 7.5 & 6.9 & 9.2 & 8.4 & 8.3 & 8.2 & 8.2 & 8.1 \\
\hline Private & 19.1 & 18.8 & 18.9 & 18.4 & 18.4 & 18.3 & 18.2 & 18.0 & 17.8 \\
\hline Gross national savings & 43.9 & 40.4 & 43.6 & 51.3 & 49.3 & 47.7 & 46.4 & 45.2 & 44.1 \\
\hline Public & 10.0 & 8.6 & 8.6 & 12.0 & 9.6 & 9.3 & 9.0 & 8.6 & 8.5 \\
\hline Private & 33.9 & 31.9 & 35.0 & 39.3 & 39.6 & 38.5 & 37.4 & 36.6 & 35.6 \\
\hline Gross official reserves (in billions of U.S. dollars) & 79.6 & 78.0 & 78.9 & 109.7 & 149.2 & 187.7 & 225.8 & 264.9 & 305.3 \\
\hline In months of imports of goods and services & 11.2 & 10.1 & 9.5 & 12.5 & 16.1 & 18.9 & 21.7 & 23.7 & 25.3 \\
\hline \multicolumn{10}{|l|}{ Memorandum items: } \\
\hline \multicolumn{10}{|l|}{ Oil and gas sector } \\
\hline Total oil and gas exports (in billions of U.S. dollars) & 82.4 & 66.2 & 81.1 & 102.9 & 103.9 & 103.2 & 104.2 & 104.8 & 107.0 \\
\hline Average oil export price (in U.S. dollars/barrel) & 79.7 & 66.2 & 80.2 & 102.2 & 99.2 & 95.3 & 93.8 & 93.4 & 93.1 \\
\hline Crude oil production (in millions of barrels/day) & 3.9 & 3.6 & 3.6 & 3.6 & 3.7 & 3.8 & 3.9 & 4.0 & 4.2 \\
\hline
\end{tabular}

Sources: Iranian authorities; and Fund staff estimates and projections.

1/ The Iranian fiscal year ends March 20.

10. The medium-term outlook is subject to considerable risks. The main risk is an acceleration of inflation if macroeconomic policies are too accommodative. An increase, at least temporarily, in unemployment during the restructuring of the corporate sector could also pose social tensions and lead to a loosening of macroeconomic policies. Progress with the reform could also slow down as a result of reform fatigue. In addition, the authorities 
stated that the sanctions impede Iran's trade transactions, and that if this continues they might halt their oil exports, with major global spillovers.

\section{Policy Discussions}

Against this background, the authorities' main challenges are to (i) maintain short term macroeconomic stability to support the reform process; (ii) transition further to a free market-based economy to foster growth and support job creation; and, (iii) strengthen the financial sector.

\section{A. Preserving Macroeconomic Stability in the Near Term}

11. The authorities concurred that maintaining macroeconomic stability is critical to the success of the reform. While the continuation of central bank credit to banks, including for housing, low lending and deposit rates, and additional fiscal spending out of extra oil revenues could support higher growth, this would likely rapidly result in higher inflation, a sizeable foreign exchange premium, capital outflows, and a weakening of the international reserve position. In turn, rampant inflation would result in a rapid erosion of domestic energy prices and of the targeted subsidies in real terms, and reduce incentives for enterprises to restructure, effectively reversing the early gains of the subsidy reform. By contrast, maintaining price stability would help prevent an upward, and potentially rapidly self-fulfilling, adjustment of inflation expectations, as shown by the experience of transition economies that have implemented in similar reforms.

12. The recent depreciation of the nominal exchange rate to a level close to the parallel market rate reflects the central bank's objective to keep a unified exchange rate. The new level of the nominal exchange rate is broadly in line with the projected inflation differential vis-à-vis Iran's main trading partner countries, and the development of fundamentals over the medium term. The central bank also reiterated its intention to reach a consensus in the Monetary and Credit Council (MCC) to increase nominal rates of return to ensure positive real rates, and discourage alternative investments such as foreign currency and gold.

13. The authorities concurred on the need for tight credit and fiscal policies to contain inflation and avoid a sizeable foreign exchange market premium. They agreed that central bank credit to banks should be restrained. In addition, staff emphasized that any potential oil revenue windfall from higher oil prices should be saved by the government, and any additional foreign exchange inflows sterilized. Staff noted that while the recent rial depreciation to the parallel exchange rate will benefit exporters and increase competitiveness of domestic producers, reductions in import tariffs for capital and intermediate goods would help reduce the inflationary impact of the depreciation.

\section{Going forward, the authorities should further liberalize prices to build on the} efficiency gains of the subsidy reform. Enterprises need to adapt to new demand and cost 
patterns by changing their production mix and technologies. The authorities should gradually relax any remaining supervision and interventions over product prices, and rely on the compensatory cash transfers and possible additional targeted social assistance to support overall demand and safeguard the most vulnerable groups.

\section{B. Ensuring the Transition to a Market-Based Economy to Foster Growth and Employment}

\section{The authorities view the transformation to a market-based economy as a means}

to enhance efficiency and increase the growth potential (Figures 4-5). Iran has a relatively well-diversified economy with a sizeable industrial base, but large scale subsidies and inefficiencies have limited Iran's ability to further develop its non-oil economy. Iran's total factor productivity growth has been low, and its energy-intensiveness increased in recent years. Despite some recent improvements, Iran only ranked 129 out of 183 in the ease of doing business in 2010. FDI flows have also remained very low by comparison to a group of comparator countries, ${ }^{4}$ largely due to international sanctions but also on account of a difficult business environment.

\section{The authorities also view job creation as a key challenge (Figure 5).}

Unemployment remains high at about 14.5 percent in 2010 , and is particularly prevalent among the youth (at about 25 percent). There is also an increasing number of new entrants into the labor force, reflecting a high number of university graduates, and increasing female participation. Staff's preliminary estimates indicate that projected growth should allow new entrants in the labor force to be employed over the medium-term. With a more labor-intensive growth (that is, a higher elasticity of employment to growth),

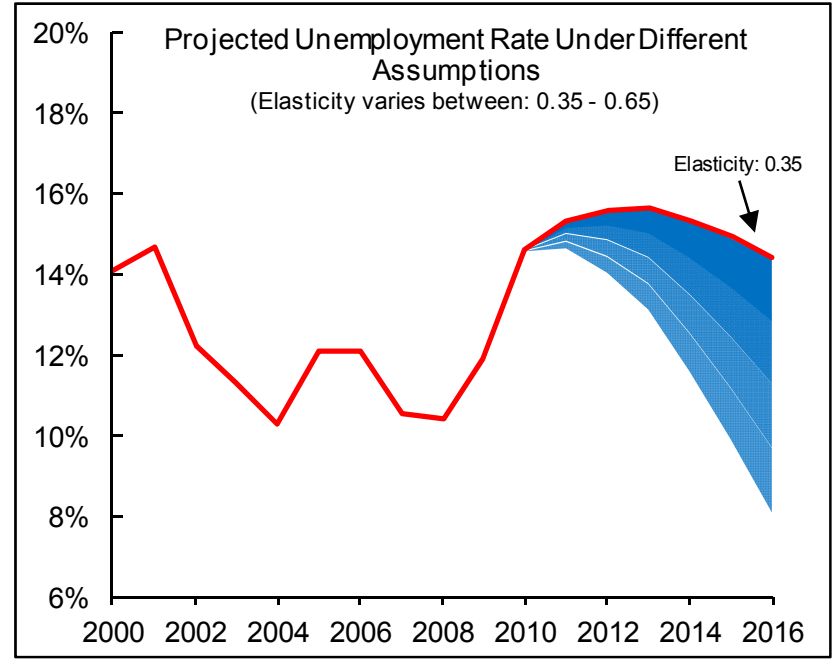
unemployment could decline in the medium-term.

\footnotetext{
${ }^{4}$ Brazil, China, Egypt, India, Russia, Saudi Arabia, Turkey.
} 
Figure 4. Iran: Exports, Employment and Productivity

Exports Breakdown (2010)
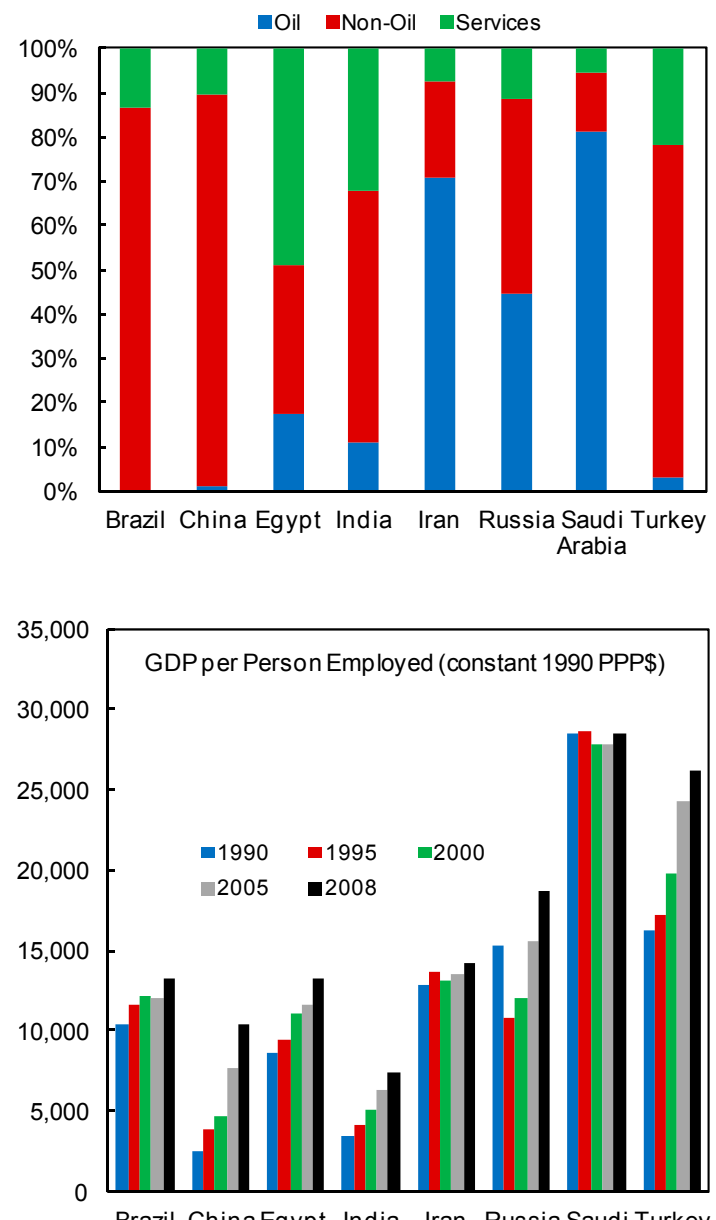

Arabia
Distribution of Employmentby Sector (2007)
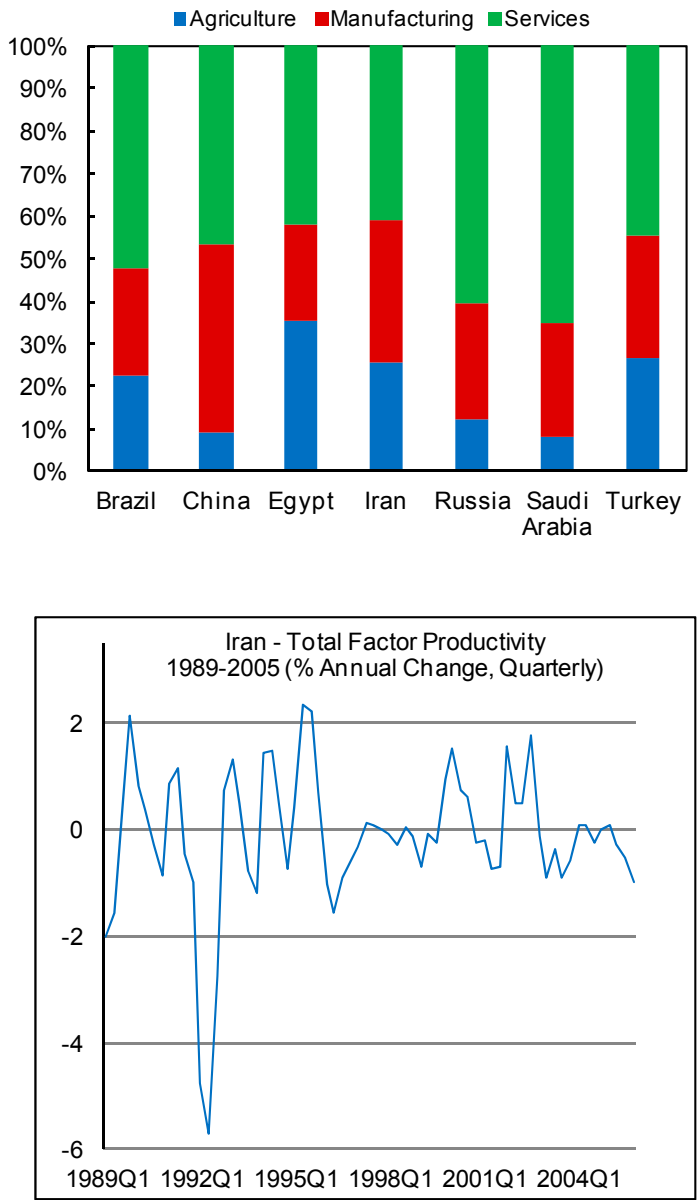
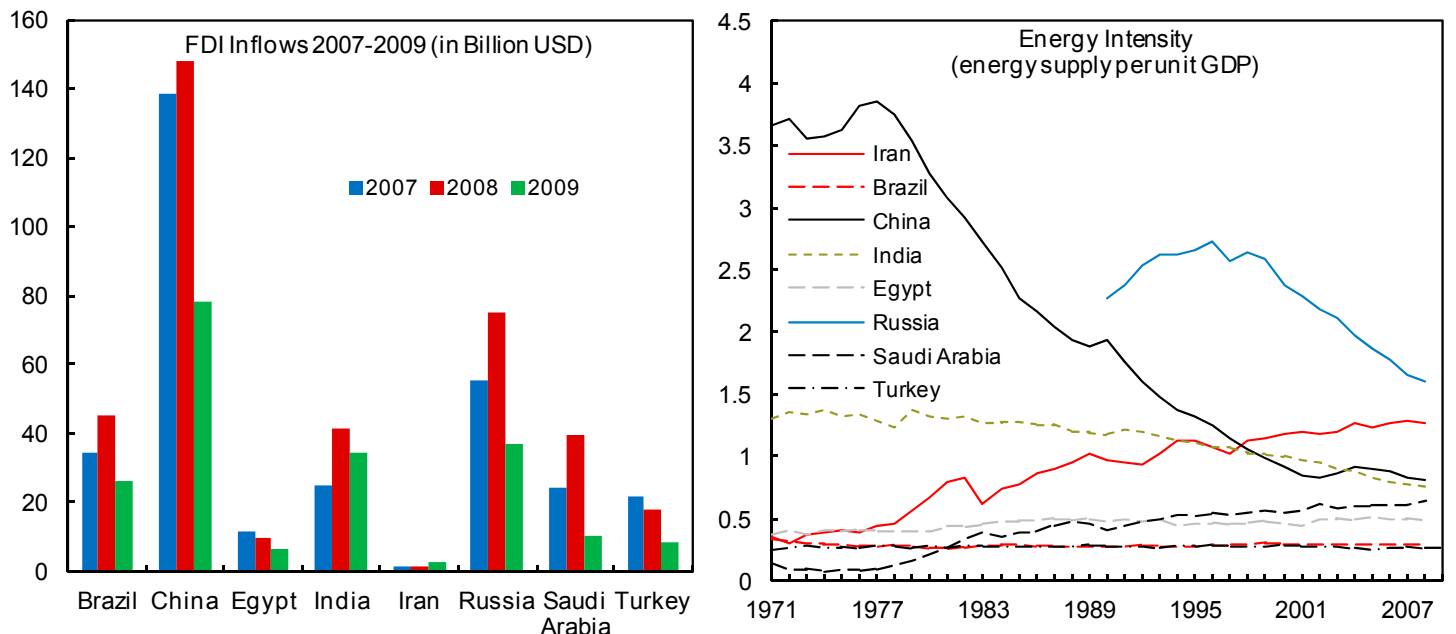

Source: World Economic Outlook, World Development In dicators, ILO, IEA database 
Figure 5. Iran: Demographics, Labor Market and Business Environment
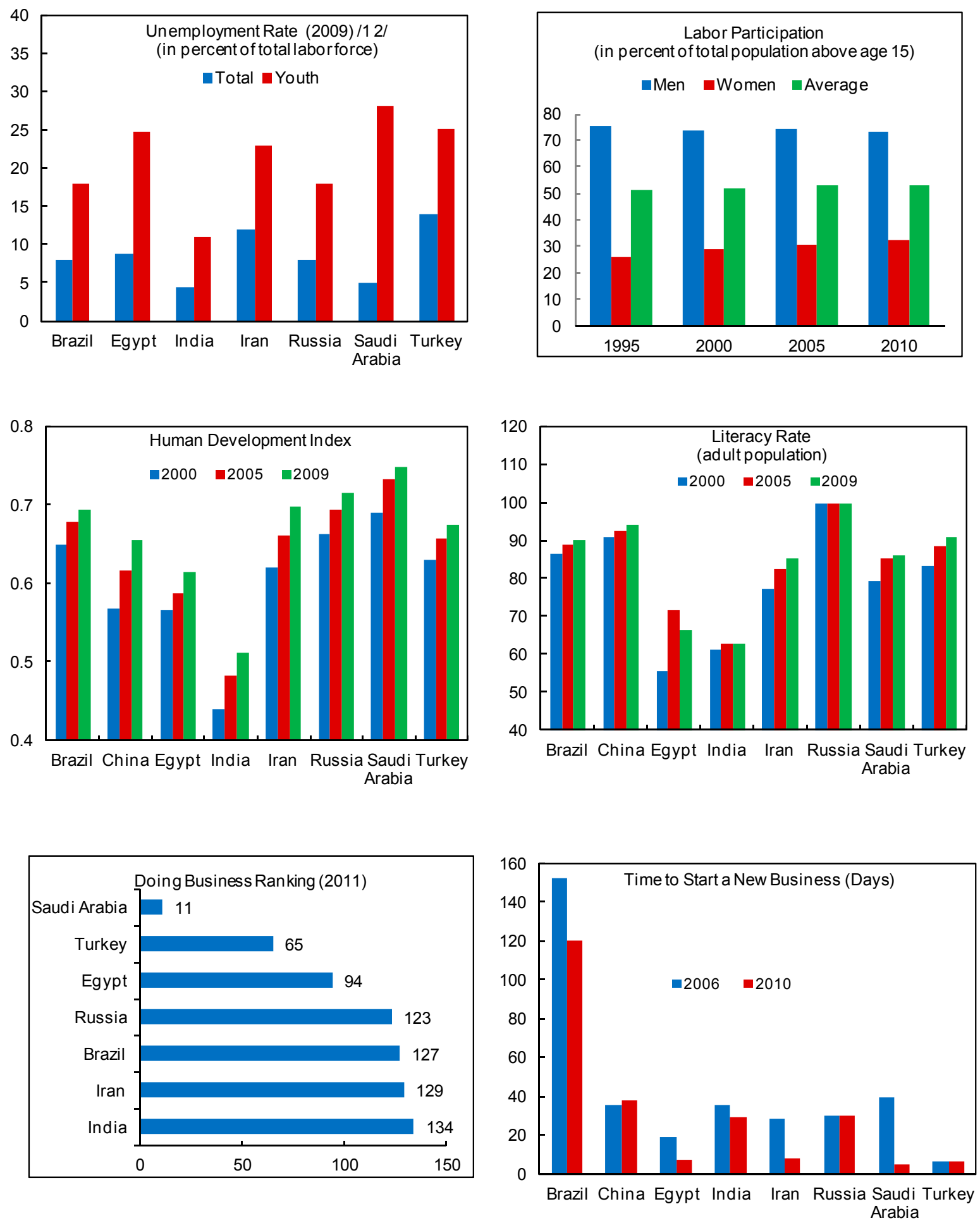

Source: World Development In dicators, ILO, WB Doing Business

1/Data on unemployment for India is from ILO and for 2000.

2|Data on youth un employment for India is for 2004. Data for Saudi Arabia is for 2008. 
17. To achieve higher growth and create jobs, the authorities have adopted a comprehensive multi-pronged strategy as reflected in their 20-year Vision document and $5^{\text {th }}$ Five-Year Development Plan (FYDP). The strategy aims at promoting a marketbased economy by reducing the role of the government, privatizing enterprises, and increasingly allowing prices to reflect market forces. To support the phasing out of subsidies, enterprises that are most energy-intensive can qualify for subsidized loans to invest in energy-efficient technologies. In addition, the government has set up incentive programs to improve management and productivity.

\section{Staff presented the experience of transition economies to underscore the} importance of creating new enterprises to facilitate a structural change. The recently launched programs to promote entrepreneurship, including private-run consultancy and training programs, are important steps in facilitating the creation and development of enterprises. The success of these initiatives should be assessed by monitoring the number of newly created enterprises and jobs. Further efforts should also be made to continue streamlining licensing procedures, particularly for small services.

\section{Adequate unemployment benefits and re-training opportunities are needed} to smooth the transition between jobs and to foster corporate restructuring. The existing unemployment benefit system (of up to 50 months) is too generous and should be set at levels that encourage workers to undergo re-training and find new employment. The planned database to match skills of job seekers and potential employers would contribute to removing frictions in the labor market. The administrative approval process to allow companies to terminate redundant workers could also be simplified.

20. To preserve macroeconomic stability and incentives for effective corporate restructuring, subsidized financial support should not be provided to nonviable enterprises. Financing for enterprise restructuring should be carried out "at arms' length," and conditional on credible restructuring plans with strong safeguards to minimize the potential impact of enterprise lobbying. The authorities should also monitor closely potential inter-enterprise arrears, trends in inventories, and the accumulation of NPLs in the banking sector for signs of financial stress. While noting staff's recommendations, the authorities believed that more financing and government intervention might be needed for enterprise restructuring.

\section{Encouraging foreign investment and accelerating the ongoing privatization} process will also support the restructuring of the economy. Greater participation of foreign investors would not only bring capital but also the much-needed modern technologies, management know-how, and access to foreign markets. The planned privatization of SMEs with listing on Iran's stock exchange would give these companies access to new capital, increase work incentives, and reduce pressures for bailouts and quasifiscal activities. 


\section{Staff noted that further enhancing transparency and data collection on economic} activity is essential to facilitate policy-making. National income statistics should be published with minimum delays. High-frequency data across various sectors should be collected and analyzed. The presentation of fiscal accounts on the basis of GFSM2001 manual would be an important step in increasing transparency on fiscal operations (Appendix II), and should be further improved by giving a more detailed presentation of transactions of financial assets and liabilities.

\section{Completing the removal of subsidies and implementing the ongoing tax and} customs reform are essential to reduce Iran's dependency on oil and natural gas. The authorities noted that the $5^{\text {th }}$ FYPD envisages a complete elimination of subsidies within five years, with domestic prices of energy and other commodities to be automatically adjusted in line with commodity prices on the Iran Mercantile Exchange. The authorities also noted that several measures should contribute to increasing non-oil revenues, including an increase of the VAT rate by one percentage point per year over the next five years, the implementation of a risk-based audit software to enhance compliance, and the introduction of a zero rate for all tax exemptions. In the area of external trade, customs tariffs and taxes should be lowered and streamlined in the medium term, and the number of importers exempt from customs should be reduced to a minimum.

\section{Strengthening the Financial Sector to Sustain Economic Development}

24. The banking system's aggregate buffers are low. The intrinsic volatility of Iran's economy calls for a higher minimum capital adequacy and a higher provision cover. This would require limiting dividend distribution of undercapitalized banks, and strengthening banks' profitability by giving banks more flexibility in setting interest rates and reducing operating costs. While the recent privatization of several public banks allows raising additional private capital, the government's recent proposal to recapitalize the remaining public banks has received only limited support from the Parliament.

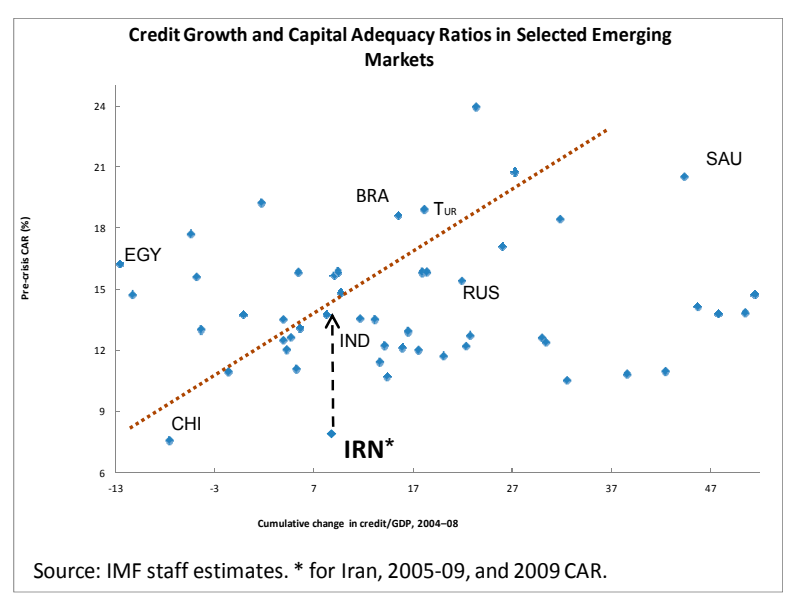


25. The recent decline in NPLs as a result of improved collection and the establishment of credit registry are important steps to improve credit allocation. Further steps to address the large NPL portfolio should include an accurate mapping of NPLs. The establishment of an asset management company would help banks focus on normal banking activity, rather than loan recovery. Removing controls on credit allocation and interest rates will also be important to ensure proper incentives for more responsible risktakings by banks.

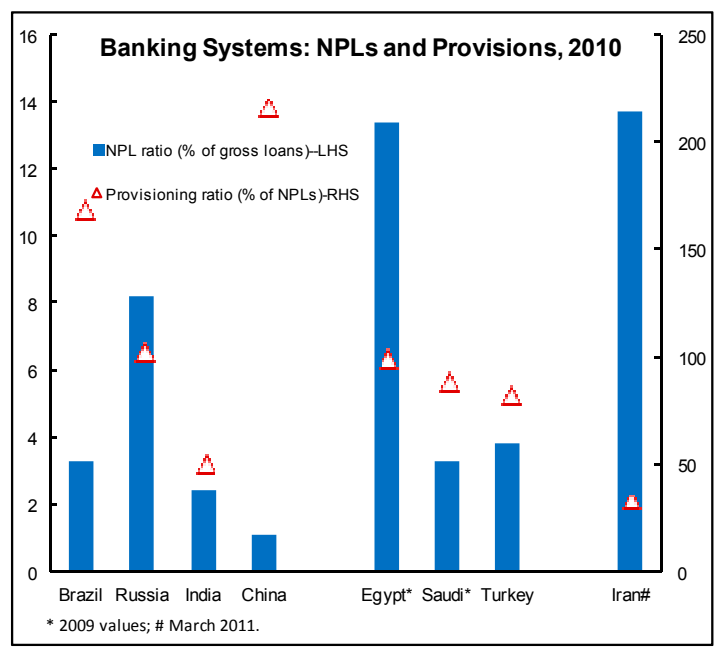

\section{Banking practices and standards of information disclosure and corporate} governance have been improving. The public listing of privatized banks has resulted in the quarterly disclosure of financial information to the Securities and Exchange Organization for half of the banking system. Furthermore, the central bank issued a regulation on loan classification and provisioning in 2007 that made core financial soundness more comparable across banks, thus helping to reveal the extent of forbearance needed for banking to function effectively in relative isolation.

27. The $5^{\text {th }}$ FYDP has increased the central bank's supervision powers. The central bank has been given authority to disqualify directors and senior officers of banks, and extend its fit and proper tests to public bank officers. The $5^{\text {th }}$ FYDP authorizes the government to allow public banks to retain after-tax profits into capital, instead of accruing them to the budget. The central bank is also revamping its regulatory framework to align it with international best practices, by increasing fines for non-compliance with regulations, introducing regulation on related party lending and large exposures, and mandatory disclosure of core financial soundness indicators. However, staff advised that it was critical that the central bank be given full autonomy to exercise its prompt enforcement powers ("cease-and-desist"), which are currently limited.

28. The launching of a centralized, real-time database with positive credit data in 2011 is a first step toward establishing a comprehensive early warning system. The early warning system should strive to anticipate vulnerabilities, based on the international experience, and monitor risk-taking in a detailed manner especially of bank exposures to concentration of risks. High dependence on funding from large depositors and connectedness also requires close monitoring. 
29. There is a need to develop a comprehensive contingency preparedness

framework. In addition to the planned deposit guarantee fund, this framework should also include a special insolvency regime that ensures swift central bank intervention in troubled banks. The crisis management framework also needs a clear lender of last resort policy, supported by minimum liquidity buffers that allow banks to withstand protracted periods of stress in funding markets without central bank support.

30. The Securities and Exchange Organization should ensure a robust investor protection framework, particularly for retail investors that use equities as a savings vehicle. To this end, it would be useful to intensify market surveillance of large trades and unusual price movements, and verify that retail accounts held by intermediaries are well segregated.

31. There has been progress towards establishing a comprehensive AML/CFT framework. A draft law on combating the financing of terrorism (CFT) has been sent to Parliament and a Financial Intelligence Unit (FIU) has been established. However, a number of shortcomings remain, in particular as regards the current draft CFT Law and the operation of the FIU. In addition, Iran has not yet ratified and implemented the 1999 International Convention on the Suppression of the Financing of Terrorism.

\section{StafF APPRAisal}

32. The Iranian economy has rebounded from the downturn in $2008 / 09$, but inflation remains high. The recovery of oil prices, a strong performance of the agricultural sector, and rapid credit expansion supported growth. Although high, inflation was contained, while external position improved in 2010/11.

33. The successful early implementation of the subsidy reform is a critical step in promoting the transition towards a market-based economy. The sharp increase in the price of energy and agricultural products in December 2010 is estimated to have removed close to 15 percent of GDP in annual product subsidies. The price increase has already resulted in a drop in energy consumption and a reduction in pollution. The distribution of cash transfers to almost all households was instrumental in securing support for the reform, improving income distribution, reducing poverty, and supporting domestic demand.

\section{The medium term growth outlook is positive, but subject to considerable}

downside risks. Although the reform may result in a temporary slowdown in growth, the combination of prudent macroeconomic policies, high oil prices, and expected efficiency gains resulting from the subsidy reform are expected to support a higher growth potential in the medium term while maintaining relative price stability. Accommodative macroeconomic policies could boost growth in the short-run, but would likely lead to much higher inflation, and weaker international reserve position. The economic sanctions are also likely to weigh on international transactions. 
35. The recent depreciation of the nominal exchange rate has brought it broadly in line with fundamentals. The staff welcomes the authorities' resolve to keep a unified exchange rate. The authorities should continue to manage flexibly the exchange rate to maintain a strong international reserve position.

36. Relatively tight credit and fiscal policies are necessary to contain inflation and avoid a sizeable foreign exchange premium. In the immediate period ahead, credit policy should remain adequately tight by ensuring positive real rates, and restraining central bank credit to banks. At the same time, the government should save any potential oil revenue windfall from higher oil prices to contain domestic demand and money growth, while the central bank should stand ready to sterilize additional foreign exchange inflows. A reduction in import tariffs for capital and intermediate goods would help reduce the inflationary impact of the depreciation.

37. The authorities' economic reform strategy, anchored in privatization, reduction of the role of government, and market-based prices for energy and agricultural goods should help achieve higher growth and create jobs. In particular, the ongoing restructuring of existing enterprises through the adoption of energy-efficient technologies, and the steadfast implementation of initiatives to support the creation of new enterprises, are critical to move Iran to a higher growth path. The development of new growth sectors will require rebalancing of the economy, and should be supported by labor market reforms, including adequate unemployment benefits. Ongoing programs to enhance skill matching and retrain workers should help remove labor market frictions. To avoid weakening incentives for effective corporate restructuring, subsidized financial support should not be provided to nonviable enterprises. At the same time, encouraging foreign investment and accelerating the ongoing privatization process will also bring new financing and support the restructuring of the economy.

38. The full removal of subsidies and steadfast implementation of the ongoing tax and customs reform are essential to reduce Iran's dependency on oil and natural gas. The subsidies should be fully eliminated over the medium term as planned under the $5^{\text {th }}$ FYDP. Measures to increase the VAT rate, enhance tax compliance, and reduce tax exemptions will increase non-oil revenues. In addition, in the area of external trade, customs tariffs and taxes should be reduced and streamlined in the medium term.

\section{The authorities' increasing focus on strengthening the banking sector is well}

placed. In particular, the intrinsic volatility of Iran's economy calls for higher minimum capital adequacy and higher provision cover, and strengthening banks' profitability by giving banks more flexibility in setting interest rates and reducing operating costs. Further steps to address the large NPL portfolio should include an accurate mapping of NPLs, and the possible establishment of an asset management company. The recent decision to increase the central bank's supervision powers is encouraging, but it is critical that the central bank be 
given full autonomy to exercise its enforcement powers. The development of a comprehensive contingency preparedness framework should include a special insolvency regime for banks in addition to the planned deposit guarantee fund. The crisis management framework also needs a clear lender of last resort policy.

40. The authorities should continue enhancing Iran's AML/CFT framework in line with international standards, with the continued cooperation of international organizations. While the transmittal to Parliament of a draft law on combating the financing of terrorism (CFT) is a welcome step in that direction, the draft CFT law should be amended to incorporate the recommendations made by staff, and subsequently adopted. The authorities should also ratify the 1999 International Convention on the Suppression of the Financing of Terrorism.

41. Further enhancing transparency and information on economic activity is essential to facilitate policy-making. High frequency data, particularly on national accounts, should be published with minimum delays.

42. The staff recommends approval of the further retention of the multiple currency practice (MCP) arising from budget subsidies for foreign exchange purchases in connection with payments of certain letters of credit through July 20, 2014. This MCP arises in connection with a scheme that has been discontinued, but where contracts have yet to expire. ${ }^{5}$ The MCP is not maintained for balance of payments reasons; it does not materially impede Iran's balance of payment adjustment, and does not discriminate among, or harm the interests of, other members. Regarding the multiple currency practice related with obligations of certain entities to surrender unused allocations of foreign exchange to the central bank of Iran at a subsidized rate the authorities informed that there are no reports in recent years pertaining to such surrender obligations and that any amounts are negligible. On the basis of the existing information, the staff proposes that at this time this multiple currency practice be considered eliminated.

43. It is recommended that the next Article IV consultation with the Islamic Republic of Iran be held on the standard 12-month cycle.

\footnotetext{
${ }^{5}$ The authorities have reported that the aggregate outstanding amount of the letters of credit for which subsidies have been provided is USD 707 million, with USD 672 million maturing by 2018 and USD 35 million maturing by 2025 and that the aggregate amount compares favorably with the USD 5 billion amount that existed in September of 2004. Staff proposes that approval be granted at this time for three year, to allow for the continual review the measure
} 
Table 1. Islamic Republic of Iran: Selected Macroeconomic Indicators, 2007/08-2011/12 1/

\begin{tabular}{|c|c|c|c|c|c|}
\hline & $2007 / 08$ & $2008 / 09$ & $2009 / 10$ & $\frac{\text { Est. }}{2010 / 11}$ & $\frac{\text { Proj. }}{2011 / 12}$ \\
\hline \multicolumn{6}{|l|}{ Oil and gas sector } \\
\hline Total oil and gas exports (in billions of U.S. dollars) & 81.6 & 82.4 & 66.2 & 81.1 & 102.9 \\
\hline Average oil export price (in U.S. dollars/barrel) & 75.8 & 79.7 & 66.2 & 80.2 & 102.2 \\
\hline \multirow[t]{2}{*}{ Crude oil production (in millions of barrels/day) } & 4.1 & 3.9 & 3.6 & 3.6 & 3.6 \\
\hline & \multicolumn{5}{|c|}{ (Annual change; in percent; unless otherwise indicated) } \\
\hline \multicolumn{6}{|l|}{ National accounts } \\
\hline Nominal GDP at market prices (in billions of Iranian rials) & $2,869,647$ & $3,387,593$ & $3,596,732$ & $4,211,939$ & $5,370,388$ \\
\hline Nominal GDP (in billions of U.S. dollars) & 309.1 & 353.8 & 362.6 & 407.4 & 480.3 \\
\hline Real GDP at factor cost & 9.9 & 0.6 & 3.5 & 3.2 & 2.5 \\
\hline Real oil and gas GDP & 4.9 & -2.0 & -3.7 & 0.0 & 1.5 \\
\hline Real non-oil GDP & 10.5 & 0.9 & 4.3 & 3.6 & 2.6 \\
\hline CPI inflation (average) & 18.4 & 25.4 & 10.8 & 12.4 & 22.5 \\
\hline GDP deflator at factor cost & 26.7 & 17.4 & 2.5 & 13.4 & 24.4 \\
\hline \multirow[t]{2}{*}{ Unemployment rate (in percent of labor force) } & 10.6 & 10.4 & 11.9 & 14.6 & $\ldots$ \\
\hline & \multicolumn{5}{|c|}{ (In percent of GDP at market prices; unless otherwise indicated) } \\
\hline Investment and savings & & & & & \\
\hline Investment & 35.6 & 37.4 & 37.4 & 37.6 & 42.6 \\
\hline Change in stocks & 11.7 & 9.0 & 11.1 & 11.8 & 15.0 \\
\hline Total fixed capital investment & 23.9 & 28.4 & 26.3 & 25.8 & 27.6 \\
\hline Public & 8.4 & 9.3 & 7.5 & 6.9 & 9.2 \\
\hline Private & 15.5 & 19.1 & 18.8 & 18.9 & 18.4 \\
\hline Gross national savings & 46.2 & 43.9 & 40.4 & 43.6 & 51.3 \\
\hline Public & 15.7 & 10.0 & 8.6 & 8.6 & 12.0 \\
\hline Private & 30.4 & 33.9 & 31.9 & 35.0 & 39.3 \\
\hline Savings/investment balance & 10.5 & 6.5 & 3.0 & 6.0 & 8.7 \\
\hline Public & 7.4 & 0.7 & 1.0 & 1.7 & 2.8 \\
\hline Private & 3.2 & 5.8 & 2.0 & 4.3 & 6.0 \\
\hline \multicolumn{6}{|l|}{ Budgetary operations } \\
\hline Revenue & 28.9 & 25.1 & 23.5 & 23.4 & 27.2 \\
\hline Taxes & 6.7 & 7.1 & 8.4 & 6.5 & 6.4 \\
\hline Other Revenue, of which & 22.2 & 18.1 & 15.1 & 17.0 & 20.8 \\
\hline Oil Revenue & 18.3 & 13.8 & 10.5 & 14.5 & 18.0 \\
\hline Expenditure & 21.5 & 24.5 & 22.5 & 21.7 & 24.4 \\
\hline Expense & 16.1 & 17.2 & 17.0 & 16.9 & 19.2 \\
\hline Net acquisition of nonfinancial assets & 5.4 & 7.2 & 5.5 & 4.9 & 5.2 \\
\hline Net lending/borrowing (Overall balance) & 7.4 & 0.7 & 1.0 & 1.7 & 2.8 \\
\hline Financial assets & 3.9 & -0.4 & -5.7 & 1.6 & -1.0 \\
\hline \multirow[t]{2}{*}{ Liabilities } & -3.5 & -1.1 & -6.8 & 0.0 & -3.7 \\
\hline & \multicolumn{5}{|c|}{ (Annual change; in percent; unless otherwise indicated) } \\
\hline \multicolumn{6}{|l|}{ Monetary sector } \\
\hline Net foreign assets & 26.9 & 6.9 & 12.4 & 26.5 & 45.0 \\
\hline Net domestic assets & 30.2 & 22.4 & 32.1 & 26.8 & 10.0 \\
\hline Credit to the private sector & 33.3 & 11.4 & 12.2 & 31.9 & 22.9 \\
\hline Narrow money (M1) & 29.7 & -2.1 & 14.2 & 24.9 & 23.5 \\
\hline Broad money (M3) & 28.6 & 15.2 & 23.5 & 26.7 & 23.8 \\
\hline \multirow[t]{2}{*}{ Velocity of broad money (ratio of GDP to M3) } & 1.8 & 1.8 & 1.6 & 1.5 & 1.5 \\
\hline & \multicolumn{5}{|c|}{ (In billions of U.S. dollars; unless otherwise indicated) } \\
\hline \multicolumn{6}{|l|}{ External sector } \\
\hline Exports of goods and services & 107.8 & 112.6 & 96.9 & 117.7 & 142.9 \\
\hline Imports of goods and services & -75.8 & -90.0 & -86.5 & -93.7 & -101.4 \\
\hline Current account balance & 32.6 & 22.9 & 10.9 & 24.4 & 42.0 \\
\hline In percent of GDP at market prices & 10.5 & 6.5 & 3.0 & 6.0 & 8.7 \\
\hline External and publicly guaranteed debt & 28.6 & 21.5 & 21.5 & 22.1 & 17.9 \\
\hline Of which: short-term debt & 9.9 & 6.6 & 8.8 & 11.7 & 11.7 \\
\hline Gross official reserves & 82.9 & 79.6 & 78.0 & 78.9 & 109.7 \\
\hline $\begin{array}{l}\text { In months of the following year's imports of goods } \\
\text { and services }\end{array}$ & 11.2 & 11.2 & 10.1 & 9.5 & 12.5 \\
\hline \multicolumn{6}{|l|}{ Memorandum items: } \\
\hline Nominal effective exchange rate, $2000 / 01=100$ & 68.2 & 67.9 & 66.2 & & $\ldots$ \\
\hline Real effective exchange rate, $2000 / 01=100$ & 137.0 & 163.6 & 174.2 & $\ldots$ & $\ldots$ \\
\hline Average exchange rate (Iranian rials per U.S. dollar) & 9,285 & 9,574 & 9,920 & 10,339 & $\ldots$ \\
\hline End-of-period exchange rate (Iranian rials per U.S. dollar) & 8,956 & 9,717 & 9,834 & 10,364 & $\ldots$ \\
\hline
\end{tabular}

Sources: Iranian authorities; and Fund staff estimates and projections.

1/ The Iranian fiscal year ends March 20. 
Table 2. Islamic Republic of Iran: Balance of Payments, 2007/08-2016/17 1/

(In millions of U.S. dollars; unless otherwise indicated)

\begin{tabular}{|c|c|c|c|c|c|c|c|c|c|c|}
\hline & \multirow[b]{2}{*}{$2007 / 08$} & \multirow[b]{2}{*}{$2008 / 09$} & \multirow[b]{2}{*}{$2009 / 10$} & \multirow{2}{*}{$\begin{array}{l}\text { Est. } \\
2010 / 11\end{array}$} & \multicolumn{6}{|c|}{ Proj. } \\
\hline & & & & & $2011 / 12$ & $2012 / 13$ & 2013/14 & $2014 / 15$ & 2015/16 & 2016/17 \\
\hline Current account balance & 32,597 & 22,903 & 10,908 & 24,406 & 41,964 & 40,685 & 39,306 & 38,950 & 39,875 & 41,207 \\
\hline (in percent of GDP at market prices) & 10.5 & 6.5 & 3.0 & 6.0 & 8.7 & 8.2 & 7.5 & 7.0 & 6.8 & 6.5 \\
\hline Trade balance & 39,428 & 31,090 & 20,935 & 37,454 & 55,647 & 54,917 & 52,461 & 50,418 & 51,183 & 50,175 \\
\hline Exports & 97,668 & 101,289 & 87,534 & 107,454 & 131,795 & 135,249 & 137,532 & 141,724 & 146,978 & 152,832 \\
\hline Oil and gas & 81,567 & 82,403 & 66,210 & 81,127 & 102,854 & 103,870 & 103,163 & 104,242 & 104,788 & 106,997 \\
\hline Non-oil and gas & 16,101 & 18,886 & 21,324 & 26,327 & 28,942 & 31,380 & 34,369 & 37,481 & 42,190 & 45,835 \\
\hline Imports & $-58,240$ & $-70,199$ & $-66,599$ & $-70,000$ & $-76,148$ & $-80,333$ & $-85,070$ & $-91,306$ & $-95,795$ & $-102,657$ \\
\hline Services (net) & $-7,473$ & $-8,549$ & $-10,451$ & $-13,458$ & $-14,134$ & $-14,728$ & $-13,701$ & $-12,068$ & $-11,974$ & $-9,722$ \\
\hline Credits & 10,093 & 11,272 & 9,403 & 10,262 & 11,126 & 11,446 & 13,791 & 17,196 & 18,520 & 22,719 \\
\hline Debits & $-17,566$ & $-19,821$ & $-19,854$ & $-23,720$ & $-25,260$ & $-26,174$ & $-27,492$ & $-29,264$ & $-30,493$ & $-32,441$ \\
\hline Transfers (net) & 642 & 362 & 424 & 410 & 451 & 496 & 546 & 600 & 666 & 753 \\
\hline Capital and financial account balance & $-2,170$ & $-3,687$ & $-10,501$ & $-20,256$ & $-11,165$ & $-1,185$ & -813 & -813 & -813 & -813 \\
\hline Foreign direct investment and portfolio equity & -299 & -247 & 260 & 0 & 0 & 0 & 0 & 0 & 0 & 0 \\
\hline Medium- and long-term debt & -62 & $-1,282$ & $-1,468$ & $-1,520$ & $-4,165$ & $-1,185$ & -813 & -813 & -813 & -813 \\
\hline Trade credit & 791 & $-3,292$ & 2,188 & 2,903 & 0 & 0 & 0 & 0 & 0 & 0 \\
\hline Other capital 2/ & $-2,600$ & 1,134 & $-11,481$ & $-21,639$ & $-7,000$ & 0 & 0 & 0 & 0 & 0 \\
\hline Errors and omissions & $-15,173$ & $-10,987$ & $-5,752$ & $-3,247$ & 0 & 0 & 0 & 0 & 0 & 0 \\
\hline Overall balance & 15,254 & 8,229 & $-5,345$ & 902 & 30,799 & 39,500 & 38,493 & 38,137 & 39,062 & 40,394 \\
\hline Change in gross official reserves (increase -) & $-15,254$ & $-8,229$ & 5,345 & -902 & $-30,799$ & $-39,500$ & $-38,493$ & $-38,137$ & $-39,062$ & $-40,394$ \\
\hline \multicolumn{11}{|l|}{ Memorandum items: } \\
\hline Gross official reserves (in millions of U.S. dollars) & 82,863 & 79,587 & 78,007 & 78,910 & 109,709 & 149,209 & 187,702 & 225,839 & 264,902 & 305,295 \\
\hline (in months of the following year's imports) & 11.2 & 11.2 & 10.1 & 9.5 & 12.5 & 16.1 & 18.9 & 21.7 & 23.7 & 25.3 \\
\hline External debt (in percent of GDP) & 9.3 & 6.1 & 5.9 & 5.4 & 3.7 & 3.4 & 3.0 & 2.7 & 2.4 & 2.1 \\
\hline
\end{tabular}

Sources: Iranian authorities; and Fund staff estimates and projections.

$1 /$ The Iranian fiscal year ends March 20.

2/ Includes Asian Clearence Union (ACU) and commercial banks 


\section{Table 3a. Islamic Republic of Iran: Statement of Government Operations 1/ 2007/08-2011/12}

(In billions of rials)

\begin{tabular}{|c|c|c|c|c|c|}
\hline & $2007 / 08$ & $2008 / 09$ & $2009 / 10$ & $\frac{\text { Est. }}{2010 / 11}$ & $\begin{array}{c}\text { Proj. } \\
2011 / 12\end{array}$ \\
\hline Revenues (a) & 828,611 & 851,710 & 846,381 & 987,113 & $1,460,176$ \\
\hline Taxes & 191,815 & 239,742 & 303,661 & 272,382 & 344,867 \\
\hline Taxes on income, profits and capital gains & 118,571 & 159,382 & 201,228 & 145,470 & 180,355 \\
\hline Taxes on property & 7,762 & 7,771 & 7,802 & 11,132 & 13,802 \\
\hline Taxes on goods and services, of which & 16,663 & 15,900 & 32,077 & 37,894 & 59,072 \\
\hline Value added tax & 0 & 2,449 & 16,154 & 20,898 & 38,000 \\
\hline Taxes on international trade and transactions & 48,819 & 56,689 & 62,554 & 77,886 & 91,639 \\
\hline Other revenue & 636,796 & 611,968 & 542,720 & 714,731 & $1,115,309$ \\
\hline Property Income, of which & 616,545 & 588,217 & 516,740 & 684,464 & $1,077,783$ \\
\hline Rents (Oil Revenue), of which & 525,857 & 466,584 & 376,277 & 609,196 & 969,085 \\
\hline National Development Fund & & & & 136,469 & 280,245 \\
\hline Expenditure (b) & 617,567 & 828,826 & 808,820 & 916,064 & $1,311,375$ \\
\hline Expense (b.1) & 461,624 & 583,973 & 611,443 & 710,957 & $1,032,775$ \\
\hline Compensation of employees & 130,614 & 175,096 & 184,073 & 204,463 & 278,355 \\
\hline Goods and services & 50,560 & 67,779 & 71,254 & 79,147 & 107,750 \\
\hline Interest payments & 7,737 & 7,974 & 5,897 & 4,563 & 1,200 \\
\hline Subsidies & 75,840 & 101,669 & 106,881 & 118,720 & 166,600 \\
\hline Grants & 25,280 & 33,890 & 35,627 & 39,573 & 53,875 \\
\hline Social benefits & 122,187 & 163,799 & 172,198 & 191,272 & 260,397 \\
\hline Other expense, of which & 49,406 & 33,766 & 35,512 & 73,220 & 164,597 \\
\hline OSF/NDF & 19,148 & 19,148 & 17,658 & 20,000 & 134,866 \\
\hline Net acquisition of nonfinancial assets (b.2) & 155,943 & 244,853 & 197,377 & 205,107 & 278,600 \\
\hline Acquisition of nonfinancial assets & 157,216 & 245,839 & 198,173 & 206,405 & 279,800 \\
\hline Disposal of nonfinancial assets & 1,273 & 986 & 796 & 1,298 & 1,200 \\
\hline Gross operating balance (a-b.1) & 366,987 & 267,738 & 234,939 & 276,156 & 427,400 \\
\hline Net lending/borrowing (a-b) (Overall balance) & 211,044 & 22,885 & 37,561 & 71,049 & 148,801 \\
\hline Financial assets & 111,387 & $-14,251$ & $-206,428$ & 69,261 & $-51,199$ \\
\hline Domestic & 111,387 & $-14,251$ & $-206,428$ & 69,261 & $-51,199$ \\
\hline Foreign & 0 & 0 & 0 & 0 & 0 \\
\hline Liabilities & $-99,657$ & $-37,135$ & $-243,989$ & $-1,787$ & $-200,000$ \\
\hline Domestic & $-99,657$ & $-37,135$ & $-243,989$ & $-1,787$ & $-200,000$ \\
\hline Foreign & 0 & 0 & 0 & 0 & 0 \\
\hline \multicolumn{6}{|l|}{ Memorandum item: } \\
\hline Non-oil net lending/borrowing (non-oil overall balance) & $-492,186$ & $-539,120$ & $-433,470$ & $-542,447$ & $-685,430$ \\
\hline
\end{tabular}

Sources: Iranian authorities; and Fund staff estimates and projections.

1/ The Statement of government operations covers budgetary central government, the Oil Stabilizaton Fund, and The National Development Fund. 
Table 3b. Islamic Republic of Iran: Financial Balance Sheet 1/

2008/09-2010/11

(In billions of rials)

\begin{tabular}{|c|c|c|c|c|c|c|c|}
\hline & \multicolumn{3}{|c|}{$2008 / 09$} & \multicolumn{2}{|c|}{$2009 / 10$} & \multicolumn{2}{|c|}{$2010 / 11$} \\
\hline & $\begin{array}{l}\text { Opening } \\
\text { balance }\end{array}$ & Transactions & $\begin{array}{l}\text { Closing/ } \\
\text { Opening } \\
\text { balance }\end{array}$ & Transactions & $\begin{array}{l}\text { Closing/ } \\
\text { Opening } \\
\text { balance }\end{array}$ & Transactions & $\begin{array}{l}\text { Closing/ } \\
\text { Opening } \\
\text { balance }\end{array}$ \\
\hline Net financial worth & $-128,769$ & 22,885 & $-105,885$ & 37,561 & $-68,324$ & 71,049 & 2,725 \\
\hline Financial assets & 460,656 & $-14,251$ & 446,406 & $-206,428$ & 239,978 & 69,261 & 309,239 \\
\hline Domestic & 460,656 & $-14,251$ & 446,406 & $-206,428$ & 239,978 & 69,261 & 309,239 \\
\hline Foreign & 0 & 0 & 0 & 0 & 0 & 0 & 0 \\
\hline Liabilities & 589,426 & $-37,135$ & 552,290 & $-243,989$ & 308,301 & $-1,787$ & 306,514 \\
\hline Domestic & 589,426 & $-37,135$ & 552,291 & $-243,989$ & 308,301 & $-1,787$ & 306,514 \\
\hline Foreign & 0 & 0 & 0 & 0 & 0 & 0 & 0 \\
\hline
\end{tabular}

Sources: Iranian authorities; and Fund staff estimates and projections.

1/ Preliminary data, subject to revision. 
Table 4. Islamic Republic of Iran: Statement of Government Operations $1 /$ 2007/08-2011/12

\begin{tabular}{|c|c|c|c|c|c|}
\hline & & & & Est. & Proj. \\
\hline & $2007 / 08$ & $2008 / 09$ & $2009 / 10$ & $2010 / 11$ & $2011 / 12$ \\
\hline & \multicolumn{5}{|c|}{ (In percent of GDP; unless otherwise indicated) } \\
\hline Revenues (a) & 28.9 & 25.1 & 23.5 & 23.4 & 27.2 \\
\hline Taxes & 6.7 & 7.1 & 8.4 & 6.5 & 6.4 \\
\hline Taxes on income, profits and capital gains & 4.1 & 4.7 & 5.6 & 3.5 & 3.4 \\
\hline Taxes on property & 0.3 & 0.2 & 0.2 & 0.3 & 0.3 \\
\hline Taxes on goods and services, of which & 0.6 & 0.5 & 0.9 & 0.9 & 1.1 \\
\hline Value added tax & 0.0 & 0.1 & 0.4 & 0.5 & 0.7 \\
\hline Taxes on international trade and transactions & 1.7 & 1.7 & 1.7 & 1.8 & 1.7 \\
\hline Other revenue, of which & 22.2 & 18.1 & 15.1 & 17.0 & 20.8 \\
\hline Property Income, of which & 21.5 & 17.4 & 14.4 & 16.3 & 20.1 \\
\hline Rents (Oil Revenue), of which & 18.3 & 13.8 & 10.5 & 14.5 & 18.0 \\
\hline National Development Fund & & & & 3.2 & 5.2 \\
\hline Expenditure (b) & 21.5 & 24.5 & 22.5 & 21.7 & 24.4 \\
\hline Expense (b.1) & 16.1 & 17.2 & 17.0 & 16.9 & 19.2 \\
\hline Compensation of employees & 4.6 & 5.2 & 5.1 & 4.9 & 5.2 \\
\hline Goods and services & 1.8 & 2.0 & 2.0 & 1.9 & 2.0 \\
\hline Grants & 0.9 & 1.0 & 1.0 & 0.9 & 1.0 \\
\hline Social benefits & 4.3 & 4.8 & 4.8 & 4.5 & 4.8 \\
\hline Net acquisition of nonfinancial assets (b.2) & 5.4 & 7.2 & 5.5 & 4.9 & 5.2 \\
\hline Acquisition of nonfinancial assets & 5.5 & 7.3 & 5.5 & 4.9 & 5.2 \\
\hline Disposal of nonfinancial assets & 0.0 & 0.0 & 0.0 & 0.0 & 0.0 \\
\hline Gross operating balance (a-b.1) & 12.8 & 7.9 & 6.5 & 6.6 & 8.0 \\
\hline Net lending/borrowing $(a-b)$ & 7.4 & 0.7 & 1.0 & 1.7 & 2.8 \\
\hline Financial assets & 3.9 & -0.4 & -5.7 & 1.6 & -1.0 \\
\hline Domestic & 3.9 & -0.4 & -5.7 & 1.6 & -1.0 \\
\hline Foreign & 0.0 & 0.0 & 0.0 & 0.0 & 0.0 \\
\hline Liabilities & -3.5 & -1.1 & -6.8 & 0.0 & -3.7 \\
\hline Domestic & -3.5 & -1.1 & -6.8 & 0.0 & -3.7 \\
\hline Foreign & 0.0 & 0.0 & 0.0 & 0.0 & 0.0 \\
\hline \multicolumn{6}{|l|}{ Memorandum item: } \\
\hline Non-oil net lending/borrowing 2/ & -25.7 & -26.2 & -15.2 & -16.6 & -16.9 \\
\hline
\end{tabular}

Sources: Iranian authorities; and Fund staff estimates and projections.

1/ The Statement of government operations covers budgetary central government, the Oil Stabilizaton Fund, and the National Development Fund.

2/ Non-oil overall balance, as a percentage of non-oil GDP 
Table 5. Islamic Republic of Iran: Central Bank Balance Sheet, 2007/08-2011/12 (In billions of rials; unless otherwise indicated)

\begin{tabular}{|c|c|c|c|c|c|}
\hline & $2007 / 08$ & $2008 / 09$ & $2009 / 10$ & $\frac{\text { Est. }}{2010 / 11}$ & $\frac{\text { Proj. }}{2011 / 12}$ \\
\hline Net foreign assets (NFA) & 651,980 & 703,329 & 707,858 & 763,411 & $1,253,507$ \\
\hline In millions of U.S. dollars & 72,798 & 72,381 & 71,981 & 73,660 & 104,459 \\
\hline Foreign assets & 742,122 & 773,352 & 767,125 & 817,822 & $1,316,507$ \\
\hline In millions of U.S. dollars & 82,863 & 79,587 & 78,007 & 78,910 & 109,709 \\
\hline Foreign liabilities $1 /$ & 90,142 & 70,023 & 59,268 & 54,411 & 63,000 \\
\hline In millions of U.S. dollars & 10,065 & 7,206 & 6,027 & 5,250 & 5,250 \\
\hline Net domestic assets (NDA) & $-250,586$ & $-139,843$ & $-84,677$ & $-64,009$ & $-387,927$ \\
\hline Net domestic credit & $-119,265$ & $-5,141$ & 93,805 & 160,582 & 11,957 \\
\hline Central government, net & $-290,877$ & $-283,735$ & $-117,918$ & $-218,676$ & $-367,477$ \\
\hline Claims & 81,197 & 74,779 & 75,850 & 144,665 & 144,665 \\
\hline Deposits & 372,074 & 358,514 & 193,768 & 363,341 & 512,142 \\
\hline Claims on banks & 137,694 & 239,758 & 168,987 & 329,647 & 329,823 \\
\hline Claims on nonfinancial public enterprises (NFPEs) & 33,918 & 38,836 & 42,737 & 49,611 & 49,611 \\
\hline Other items net, excluding central bank participation papers (CPPs) & $-131,321$ & $-134,701$ & $-178,483$ & $-224,591$ & $-399,884$ \\
\hline Base money & 382,980 & 556,925 & 621,256 & 697,849 & 863,786 \\
\hline Currency & 88,047 & 206,352 & 231,054 & 286,598 & 347,152 \\
\hline Currency in circulation & 79,909 & 157,764 & 192,314 & 225,155 & 272,728 \\
\hline Cash in vaults & 8,138 & 48,588 & 38,740 & 61,443 & 74,425 \\
\hline Reserves & 277,452 & 334,495 & 373,308 & 397,423 & 499,694 \\
\hline Required reserves & 235,841 & 225,228 & 242,841 & 289,165 & 360,029 \\
\hline Excess reserves & 41,611 & 109,267 & 130,466 & 108,259 & 139,665 \\
\hline Deposits of NFPE and municipalities & 17,481 & 16,078 & 16,895 & 13,828 & 16,939 \\
\hline Other liabilities & 18,414 & 6,561 & 1,925 & 1,552 & 1,794 \\
\hline CPPs & 16,372 & 0 & 0 & 0 & 0 \\
\hline Foreign currency deposits of NFPEs and municipalities & 2,042 & 6,561 & 1,925 & 1,552 & 1,794 \\
\hline \multicolumn{6}{|l|}{ Memorandum items: } \\
\hline \multicolumn{6}{|l|}{ End-period change (in percent of base money) } \\
\hline Base money & 31.1 & 45.4 & 11.6 & 12.3 & 23.8 \\
\hline NFA & 58.6 & 13.4 & 0.8 & 8.9 & 70.2 \\
\hline NDA (net of other liabilities) & -27.5 & 32.0 & 10.7 & 3.4 & -46.5 \\
\hline
\end{tabular}

Sources: Central Bank of Iran; and Fund staff estimates and projections.

$1 /$ Includes some liabilities in foreign currency to residents. 
Table 6. Islamic Republic of Iran: Monetary Survey, 2007/08-2011/12 1/

(In billions of rials; unless otherwise indicated)

\begin{tabular}{|c|c|c|c|c|c|}
\hline & $2007 / 08$ & 2008/09 & $2009 / 10$ & $\frac{\text { Est. }}{2010 / 11}$ & $\frac{\text { Proj. }}{2011 / 12}$ \\
\hline Net foreign assets (NFA) & 833,482 & 891,084 & $1,001,319$ & $1,266,385$ & $1,835,878$ \\
\hline In millions of U.S. dollars & 93,064 & 91,704 & 101,822 & 122,191 & 152,990 \\
\hline Foreign assets & $1,040,061$ & $1,053,093$ & $1,175,978$ & $1,499,464$ & $2,105,750$ \\
\hline In millions of U.S. dollars & 116,130 & 108,376 & 119,583 & 144,680 & 175,479 \\
\hline Foreign liabilities 2/ & 206,580 & 162,008 & 174,658 & 233,080 & 269,872 \\
\hline In millions of U.S. dollars & 23,066 & 16,673 & 17,761 & 22,489 & 22,489 \\
\hline Net domestic assets (NDA) & 946,434 & $1,158,839$ & $1,531,346$ & $1,942,446$ & $2,135,961$ \\
\hline Net domestic credit & $1,790,723$ & $2,035,525$ & $2,522,433$ & $3,312,569$ & $3,914,280$ \\
\hline Net credit to government & $-288,577$ & $-263,643$ & $-41,904$ & $-49,132$ & $-197,933$ \\
\hline Claims on nonfinancial public enterprises (NFPEs) & 91,913 & 84,614 & 79,733 & 84,474 & 84,474 \\
\hline Claims on the private sector $3 /$ & $1,987,387$ & $2,214,554$ & $2,484,604$ & $3,277,228$ & $4,027,739$ \\
\hline Of which: Foreign currency claims $3 /$ & 323,661 & 348,003 & 348,003 & 348,003 & 522,937 \\
\hline Other items, net, excluding CPPs & $-844,289$ & $-876,686$ & $-991,088$ & $-1,370,123$ & $-1,778,319$ \\
\hline Broad money (M3) & $1,779,916$ & $2,049,924$ & $2,532,665$ & $3,208,832$ & $3,971,839$ \\
\hline M2 & $1,657,774$ & $1,917,444$ & $2,372,784$ & $2,962,702$ & $3,681,157$ \\
\hline Cash & 79,909 & 157,764 & 192,314 & 225,155 & 272,728 \\
\hline Deposits & $1,577,865$ & $1,759,680$ & $2,180,470$ & $2,737,547$ & $3,408,429$ \\
\hline Demand deposits & 473,279 & 383,796 & 426,278 & 547,389 & 681,536 \\
\hline Time deposits & $1,104,586$ & $1,375,884$ & $1,754,192$ & $2,190,158$ & $2,726,893$ \\
\hline CPPs held by nonbanks & 16,372 & 0 & 0 & 0 & 0 \\
\hline Foreign currency deposits & 105,770 & 132,480 & 159,882 & 246,130 & 290,682 \\
\hline \multicolumn{6}{|l|}{ Memorandum items: } \\
\hline Base money & 382,980 & 556,925 & 621,256 & 697,849 & 863,786 \\
\hline M1 & 553,188 & 541,560 & 618,592 & 772,544 & 954,264 \\
\hline Multiplier (M3/base money) & 4.65 & 3.68 & 4.08 & 4.60 & 4.60 \\
\hline Income velocity of M3 & 1.81 & 1.77 & 1.57 & 1.47 & 1.50 \\
\hline \multicolumn{6}{|l|}{ Annual percentage change } \\
\hline NFA & 26.9 & 6.9 & 12.4 & 26.5 & 45.0 \\
\hline NDA & 30.2 & 22.4 & 32.1 & 26.8 & 10.0 \\
\hline Base money & 31.1 & 45.4 & 11.6 & 12.3 & 23.8 \\
\hline M1 & 29.7 & -2.1 & 14.2 & 24.9 & 23.5 \\
\hline M2, excluding foreign currency deposits and CPPs & 27.9 & 15.7 & 23.7 & 24.9 & 24.2 \\
\hline M3 & 28.6 & 15.2 & 23.5 & 26.7 & 23.8 \\
\hline Credit to the private sector and NFPEs in rials & 32.8 & 11.1 & 13.6 & 36.0 & 19.1 \\
\hline Credit to private sector in rials & 35.7 & 12.2 & 14.5 & 37.1 & 19.6 \\
\hline Total claims on private sector & 33.3 & 11.4 & 12.2 & 31.9 & 22.9 \\
\hline
\end{tabular}

Sources: Central Bank of Iran; and Fund staff estimates and projections.

1/ The Iranian fiscal year ends March 20.

2/ Includes some liabilities in foreign currency to residents.

3 / Includes on-lending of the Oil Stabilization Fund resources and claims under letters of credit

for trade financing. 
Table 7. Islamic Republic of Iran: Vulnerability Indicators, 2007/08-2010/11 1/

\begin{tabular}{|c|c|c|c|c|}
\hline & $2007 / 08$ & 2008/09 & $2009 / 10$ & 2010/11 6/ \\
\hline \multicolumn{5}{|l|}{ External solvency indicators } \\
\hline Real effective exchange rate (REER) (end of period; percent change) & 6.1 & 19.4 & 6.5 & $\ldots$ \\
\hline Total public and publicly guaranteed external debt (in billions of U.S. dollars) & 28.6 & 21.5 & 21.5 & 22.1 \\
\hline (In percent of GDP) & 9.3 & 6.1 & 5.9 & 5.4 \\
\hline Short-term external debt (in billions of U.S. dollars) & 9.9 & 6.6 & 8.8 & 11.7 \\
\hline (In percent of GDP) & 3.2 & 1.9 & 2.4 & 2.9 \\
\hline (In percent of exports of goods and services) $2 /$ & 9.4 & 6.0 & 9.2 & 10.0 \\
\hline External debt service (in percent of exports of goods and services) 2/3/ & 5.3 & 3.0 & 1.8 & 1.5 \\
\hline \multicolumn{5}{|l|}{ External liquidity indicators } \\
\hline Total official reserves (in billions of U.S. dollars) & 82.9 & 79.6 & 78.0 & 78.9 \\
\hline (In months of the following year's imports of goods and services) 2/ & 11.2 & 11.2 & 10.1 & 9.5 \\
\hline (In percent of short-term external debt) & 838 & 1206 & 888 & 675 \\
\hline Commercial banks net foreign assets (in billions of U.S. dollars) & 20.3 & 19.3 & 29.8 & 48.5 \\
\hline Foreign assets & 33.3 & 28.8 & 41.6 & 65.8 \\
\hline Foreign liabilities 4/ & 13.0 & 9.5 & 11.7 & 17.2 \\
\hline Oil and oil-related exports (in percent of exports of goods) & 83.5 & 81.4 & 75.6 & 75.5 \\
\hline \multicolumn{5}{|l|}{ Public sector solvency indicators } \\
\hline Public and publicly guaranteed debt (in percent of GDP) & 7.7 & 7.1 & 8.9 & 11.6 \\
\hline Oil revenue (in percent of total revenue) & 63.5 & 54.8 & 44.5 & 61.7 \\
\hline \multicolumn{5}{|l|}{ Financial sector indicators } \\
\hline Risk-weighted capital adequacy of banks (in percent) 5/ & 9.0 & 8.8 & 9.6 & 8.4 \\
\hline Ratio of nonperforming loans of banks (in percent of total loans) 5 / & 16.9 & 19.1 & 18.1 & 13.7 \\
\hline Loan provisions as a percentage of nonperforming loans & 12.3 & 8.3 & 17.0 & 35.1 \\
\hline Net profit margin of banks to total assets (in percent) & 0.7 & 0.8 & 0.8 & $\ldots$ \\
\hline Net domestic credit (percent change) & 26.6 & 13.7 & 23.9 & 31.3 \\
\hline Private sector credit in local currency (percent change) & 33.3 & 11.4 & 12.2 & 31.9 \\
\hline Net domestic credit (in percent of GDP) & 62.4 & 60.1 & 70.1 & 78.6 \\
\hline \multicolumn{5}{|l|}{ Market assessment/financial market indicators } \\
\hline Stock market price index (percent change; end-of-period) & 2.7 & -21.0 & 57.4 & 85.8 \\
\hline Stock market capitalization (in percent of GDP) & 17.8 & 12.7 & 19.9 & 27.7 \\
\hline
\end{tabular}

Sources: Iranian authorities; and Fund staff estimates.

1/ The Iranian fiscal year ends March 20.

2/ Excluding interest receipts and payments.

3 / Excluding service of short-term external debt.

4/ Including contingent liabilities under letters of credit.

5/ Islamic banks exhibit important differences in their risk profile and asset classification, which limit international comparability.

6/ Estimate. 


\section{APPENDiX I. Iran: EXChange RATE ASSESSMENT}

Preliminary estimates from CGER-type methodologies for exchange rate assessment indicate that the Iranian Rial is broadly in line with fundamentals. ${ }^{1}$

1. The real exchange rate has appreciated by 3 percent in 2010 . The real effective exchange rate continued its appreciating trend during the last five years. The trade-weighted real effective exchange rate (REER) index appreciated by 33 percent cumulatively between end 2007 and 2010 while the appreciation slowed down to 3 percent in 2010. The nominal effective exchange rate, on the other hand, continued a depreciating trend with a brief hiatus in 2009.

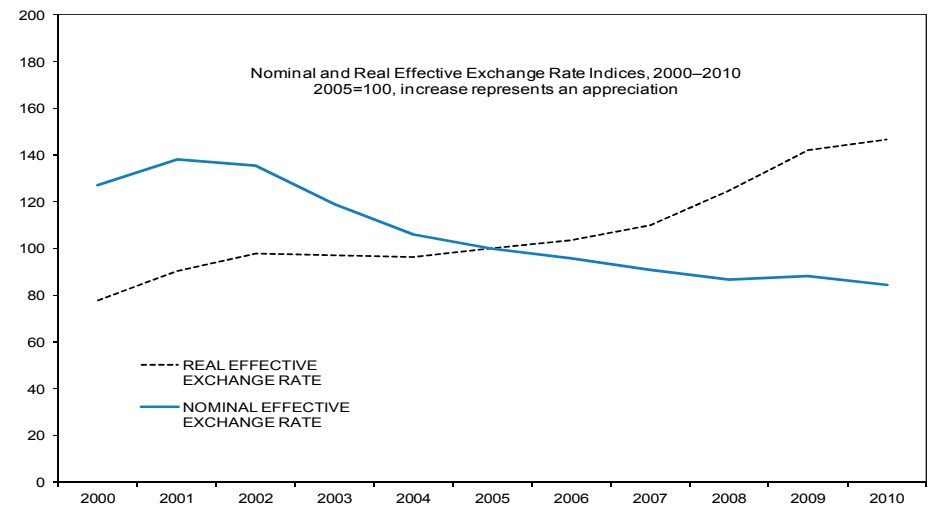

2. The equilibrium real exchange rate (ERER) approach suggests that the rial is broadly in line with equilibrium. The estimation suggests that while the rial was undervalued between 2004 and 2008, it became briefly overvalued late 2008 to mid 2009 and followed an undervalued trend since then. The misalignment of the equilibrium REER from the actual REER (as of April 2011) is a small deviation of about 1.5 percent undervaluation. If the nominal exchange rate remained stable, it would be slightly overvalued by the end of the year with a projected inflation of about 22 percent.

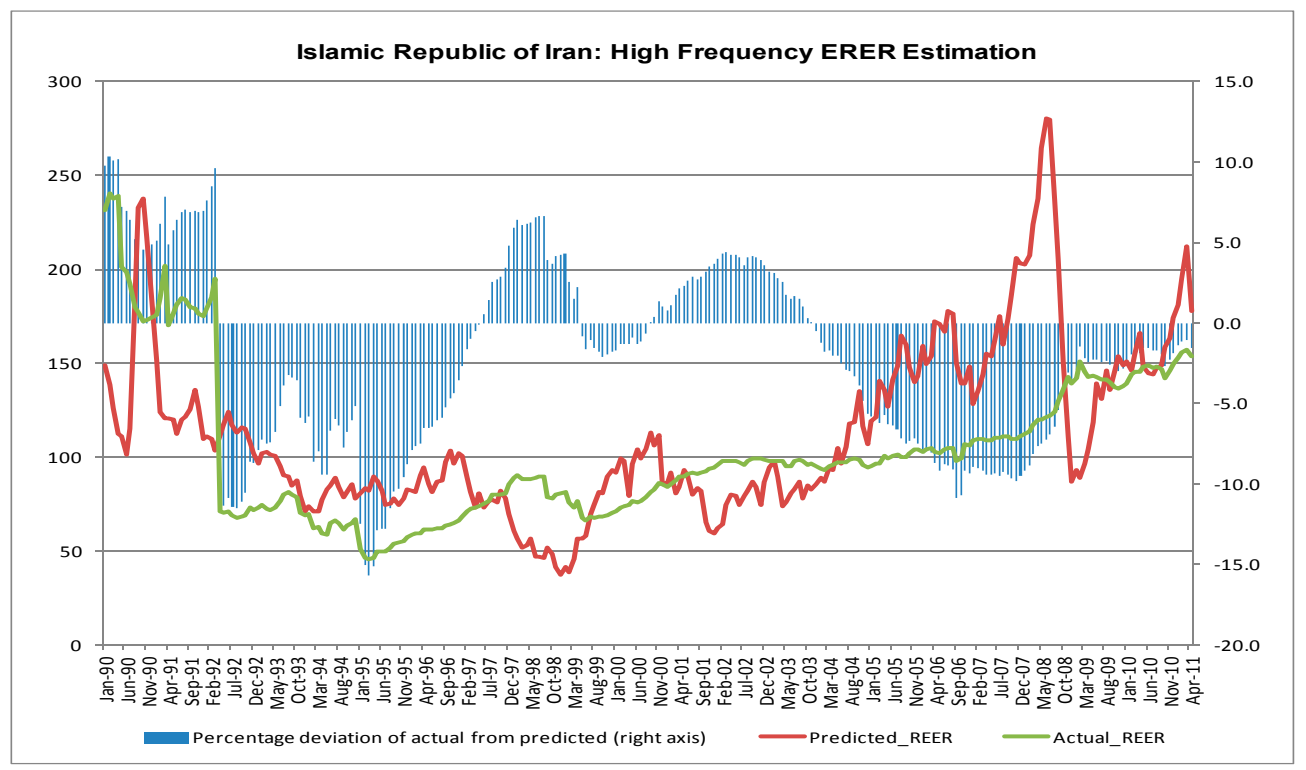

\footnotetext{
${ }^{1}$ The CGER econometric models used for the exchange rate assessment are different than the Staff Report for 2009 Article IV Consultations.
} 


\section{The macroeconomic balance approach suggests that while the Iranian rial is} close to its estimated norm during 2010 and over the medium term. The macroeconomic balance approach estimates an equilibrium current account (norm) from a set of fundamentals employing a generalized method of moments (GMM) technique. ${ }^{2}$ As Iran: Current Account Balance, Actual and Estimated Norms 1/ shown, the estimation yields a current account norm surplus for Iran of 6.7 percent of GDP in 2016. By comparing this norm to the actual (2010) and projected current account positions (2016) — a surplus of 6 and 6.5 percent of GDP, respectively, which lie within one standard error of the prediction - suggests no evidence of exchange rate misalignment i.e. the REER is broadly in line with its medium term fundamentals. As for

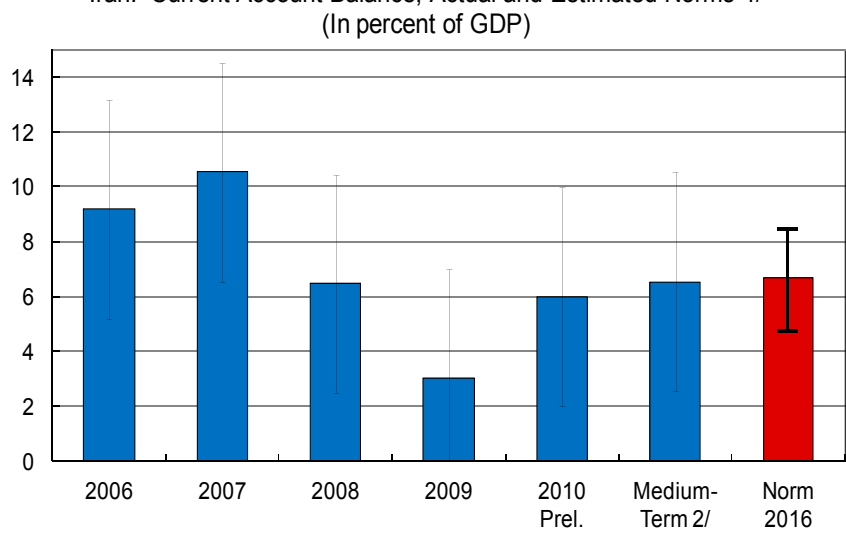

Sources: Fund staff estimates and projections.

$1 /$ In computing the norms, medium-term values of the fundamentals (including the non-oil ffiscal balance, oil trade balance, fand oil and gas reserves) are drawn from staff projections.

Band is \pm 1 standard error of the prediction.
$2 /$ Based on Fund staff estimates. For the 2010 assessment, the medium-term is 2016 . other oil producing countries, these estimates are subject to a high degree of uncertainty.

\footnotetext{
${ }^{2}$ Beidas-Strom and Cashin (forthcoming), “Are Middle Eastern Current Account Imbalances Excessive?”
} 


\section{ApPendix II: Migration Of Iran fiscal Presentation Into the GFSM 2001 Presentation}

\section{BACKGROUND}

1. In March 2010, the Executive Board of the IMF approved the Government Finance Statistics Manual 2001 (GFSM 2001) as the standard for presentation of the fiscal data in Fund's reports. ${ }^{1}$ As a result, starting May 2011, staff reports should include a fiscal presentation based on the GFSM 2001. The proposed fiscal presentation consists of two tables: a statement of operations, and an integrated financial balance sheet (Figure 1).

Figure1. Staff report fiscal presentation based on GFSM 2001

Table 1: Government Operations

Table (Generic Version)

\begin{tabular}{|l|}
\hline Revenue \\
Less \\
Expense( $\approx$ current expenditure) \\
Equals \\
Operating balance \\
Less \\
\hline Net investment in nonfinancial assets \\
\hline Equals \\
\hline Net lending/borrowing \\
\hline (financed by) \\
\hline Transactions in financial assets \\
\hline Less \\
\hline Transactions in liabilities \\
\hline
\end{tabular}

Table 2: Government Integrated Financial Balance Sheet (Generic Version)

(Opens Year t)
\begin{tabular}{|l|l|l|l|}
\hline $\begin{array}{l}\text { Opening net financial } \\
\text { worth }\end{array}$ & Net lending/borrowing & $\begin{array}{l}\text { Change in net financial } \\
\text { worth from other } \\
\text { economic flows }\end{array}$ & $\begin{array}{l}\text { Closing net financial } \\
\text { worth }\end{array}$ \\
\hline Opening financial assets & $\begin{array}{l}\text { Transactions in financial } \\
\text { assets }\end{array}$ & $\begin{array}{l}\text { Other economic flows in } \\
\text { financial assets }\end{array}$ & Closing financial assets \\
\hline Less & Less & Less & Less \\
\hline Opening liabilities & Transactions in liabilities & $\begin{array}{l}\text { Other economic flows in } \\
\text { liabilities }\end{array}$ & Closing liabilities \\
\hline
\end{tabular}

2. In line with the Board's decision, the fiscal presentation for Iran adopted in this Article IV consultation report is presented on the basis of a GFSM 2001. Migrating to the GFSM 2001 methodology required mapping the fiscal source data, discussing with the authorities data issues related to the new classification, filling in data gaps, and integrating the new fiscal database into the macroeconomic framework.

\footnotetext{
${ }^{1}$ Executive Board decision No. 14565-10/20
} 


\section{Source Data}

3. The source data provided by the authorities cover the budget operations, transactions of the Oil Stabilization Fund, and the National Development Fund.

4. The main source data are two tables compiled by the central bank that provide annual data on the budget execution: Table 16 "Central Government Fiscal Position" and Table 17 "Central Government Revenue." The presentation in these two tables is largely based on a budget classification compliant with the GFSM 2001 for revenue and expense. However, the breakdown of the nonfinancial assets and the financing data is not fully in line with the GFSM 2001: (i) oil revenue is classified as disposal of nonfinancial assets, as opposed to revenue in GFSM 2001; and (ii) the financing data is divided into two categories, (a) the disposal of financial assets which consists of the disposal of financial assets and the incurrence of liabilities, and (b) the acquisition of financial assets which consists of the acquisition of financial assets and a decrease of liabilities. Additional information related to the transactions of OSF and NDF were also mapped and included in the fiscal presentation.

\section{Mapping the Fiscal Data into the GFSM 2001 Presentation}

5. Regarding the statement of operations, the work consisted of bridging the source data and classifying each transaction into the correspondent classification in GFSM 2001. In order to insure the proper bridging of these data, the mission met with officials from the Central Bank and the Ministry of Finance to get clarifications on the treatment of some transactions and discussed the appropriate classification in the GFSM 2001 presentation. As for the financial balance, the data currently presented only covers part of the stock of financial assets and liabilities of the government, which was derived from the monetary survey.

6. As a result of the mapping (Table 1), the fiscal presentation of Iran is currently presented based on the format of the GFSM 2001. Moving forward, improvements are needed mainly for the transactions of financial assets and liabilities and the financial balance sheet. Additional data provided by the authorities on financing flows and stocks would help achieve a more detailed fiscal presentation. 


\section{Table 1. Reclassification of the Previous Fiscal Presentation in the Current Fiscal Presentation}

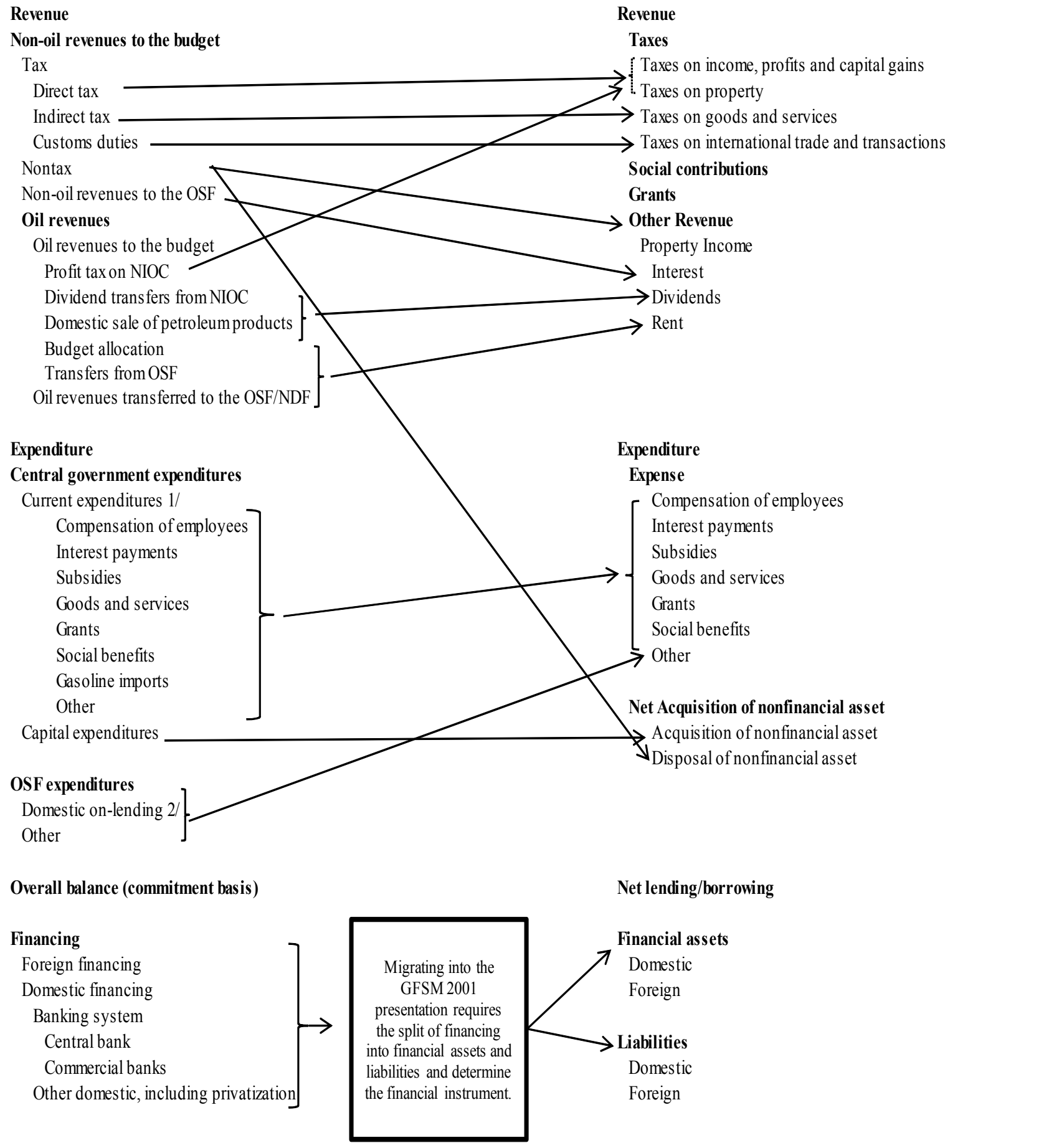

1/ The breakdown of current expenditures is in lign with GFSM 2001 except for gasoline imports that was added to goods and services.

2/ The operations of lending operated by OSF and starting 2011 by NDF are classified as other expense - capital transfers. In fact, these operations consists of lending to private corporations. However, the repayment of these loans is very minimal. 
INTERNATIONAL MONETARY FUND

ISLAMIC REPUBLIC OF IRAN

Staff Report for the 2011 Article IV Consultation

Informational Annex

Prepared by Middle East and Central Asia Department

(In consultation with other Departments)

July 5, 2011

Contents

Page

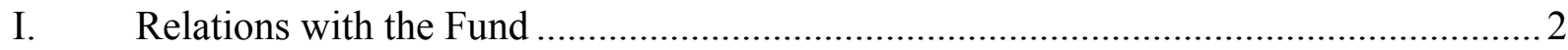

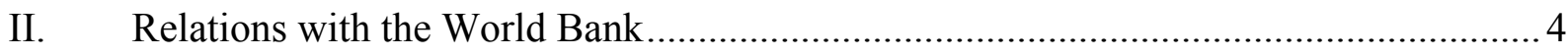

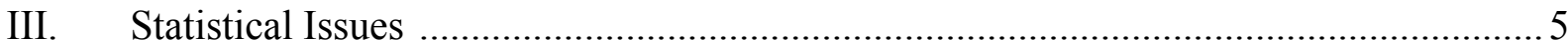


APPENDIX I. ISLAMIC REPUBLIC OF IRAN: RELATIONS WITH THE FUND

(As of May 31, 2011)

I. Membership Status

II. General Resources Account

Quota

Fund holdings of currency

Reserve position

III. SDR Department

Net cumulative allocation

Holdings $\underline{\text { SDR Million }}$

$1,497.20$

$1,497.20$

0.01

$\begin{array}{cc}\text { SDR Million } & \text { Percent of Allocation } \\ 1,426.06 & 100.00 \\ 1,536.02 & 107.71\end{array}$

IV. Outstanding Purchases and Loans None

V. Financial Arrangements None

VI. Projected Payments to Fund

(SDR Million; based on existing use of resources and present holdings of SDRs)

\begin{tabular}{llrl}
\multicolumn{3}{c}{ Forthcoming } \\
\hline$\underline{2011}$ & $\underline{2012}$ & $\underline{2013}$ & $\underline{2014}$
\end{tabular}

Principal

Charges/Interest

Total

$\begin{array}{lll}\underline{0.02} & \underline{0.02} & \underline{0.02} \\ 0.02 & 0.02 & 0.02\end{array}$

\section{Nonfinancial Relations}

\section{Exchange System}

The exchange rate is determined in the interbank foreign exchange market. The Islamic Republic of Iran maintains a de jure managed floating arrangement against a basket of currencies. The rial gradually depreciated against a composite of currencies that included the Euro, the U.S. dollar, and the Japanese yen. Effective January 4, 2008, the classification of the de facto exchange rate arrangement was changed from a conventional pegged arrangement to a crawling peg, and later in 2008, in view of further increase in exchange rate flexibility, the arrangement was reclassified to other managed arrangement. With effect from September 6, 2004, the Islamic Republic of Iran accepted the obligations under Article VIII, 
Sections 2, 3, and 4 of the Fund's Articles of Agreement. Iran maintains one exchange restriction and a multiple currency practice subject to Fund jurisdiction under Article VIII, Sections 2(a) and 3.

a. The exchange restriction arises from limitations on the transferability of rial profits from certain investments under the Foreign Investment Promotion and Protection Act and from limitations on other investment-related current international payments under this act.

b. The multiple currency practice arises from the budget subsidies for foreign exchange purchases in connection with payments of certain letters of credit opened prior to March 21, 2002 under the previous multiple exchange rate system.

\section{Last Article IV Consultation}

The last Article IV consultation was concluded by the Executive Board on Feb 3, 2010.

\section{Technical Assistance}

Since FY 2007, Iran received the following technical assistance:

\section{FAD}

FY 2009 - Tax administration and VAT

FY 2010 - Tax policy

FY 2010 - Tax Administration- Risk Management and Audit

\section{LEG}

FY 2007 - Anti-Money Laundering/Combating Financing of Terrorism regulations

FY 2009 - Anti-Money Laundering/Combating Financing of Terrorism regulations

\section{MCM}

FY 2007 - Banking regulation and supervision

FY 2008 - Technical assistance assessment visit

FY 2008 - Currency reform

FY 2008 - Macroeconomic and monetary modeling

FY 2010 - Macrofinancial Policies and Financial Stability (with MCD and LEG) 


\section{APPENDIX II. ISLAMIC REPUBLIC OF IRAN: RELATIONS WITH THE WORLD BANK}

The Islamic Republic of Iran: JMAP Implementation

\begin{tabular}{|c|c|c|}
\hline Are & Product & Delivery \\
\hline \multicolumn{3}{|l|}{ World } \\
\hline Poverty & Employers Survey Analysis & FY09 \\
\hline Energy and & Electricity Pricing and Power Sector Reform TA & FY09 \\
\hline Energy and & Promotion of Renewable Energy TA & FY09 \\
\hline Transport & Transport TA & FY10 \\
\hline Country Monitoring & Economic Monitoring & FY12 \\
\hline \multicolumn{3}{|l|}{ IM } \\
\hline \multirow[t]{6}{*}{ Financial } & 2009 Article IV Consultation Report & \\
\hline & Technical Assistance & \\
\hline & Currency Reform & FY2008-10 \\
\hline & Monetary Policy Modelling & FY2009-10 \\
\hline & & FY2009-10 \\
\hline & Bank Restructuring and Supervision & FY 2010 \\
\hline \multirow[t]{5}{*}{ Fiscal } & 2009 Article IV Consultation Report & \\
\hline & Selected Issues Paper & \\
\hline & Energy Sector Reform & FY2009-10 \\
\hline & Technical Assistance & \\
\hline & Major Tax Reforms & FY2009-10 \\
\hline \multirow[t]{4}{*}{ Trade and Exchange Restrictions } & 2009 Article IV Consultation Report & \\
\hline & Exchange Rate Assessment CGER Methodologies & \\
\hline & Technical Assistance & \\
\hline & $\begin{array}{l}\text { Implementing changes to the foreign investment } \\
\text { regulatory framework }\end{array}$ & FY2009-10 \\
\hline
\end{tabular}




\section{APPENDIX III. ISLAMIC REPUBLIC OF IRAN: STATISTICAL ISSUES}

Data provision to the Fund is generally adequate for effective surveillance; however, the data are reported with significant delays. The Central Bank of Iran (CBI) disseminates key statistical aggregates in its quarterly Economic Trends, also available at $<$ http://www.cbi.ir/e/ $>$. Since 2002, the Fund's Statistics Department has assisted the authorities in their efforts to subscribe to the Special Data Dissemination Standard (SDDS). The progress, however, has been slow and gaps in meeting SDDS requirements for data coverage, periodicity, and timeliness remain.

\section{Real sector statistics}

- National accounts statistics are reasonably sound but should be released in a timely manner. Improvements have been made in the coverage of the informal economy. However, there is scope for further progress, especially in the coverage of small-scale industries and services. Also, the CBI and the Statistical Center of Iran (SCI) have undertaken to review and unify their respective GDP estimates.

- $\quad$ Price statistics are sound and released in a timely manner. The official labor market statistics are released by the SCI, and are based on the definitions recommended by the International Labor Organization (ILO). The data are based on an urban and rural population sample of about 100,000 households, and the threshold for considering a person employed is two days a week. Labor market statistics, however, could benefit from further improvement, particularly with regard to employment and wage data.

\section{Government finance statistics}

- $\quad$ The data are compiled in accordance with the Government Finance Statistics Manual 2001 (GFSM2001) for the budgetary central government operations in addition to the Oil Stabilization Fund and the National Development Fund. The data consist of a statement of operations and an integrated financial balance sheet.

- Data on central government operations cover the general budget, the special purpose funds, and certain transactions with the Social Security Organization. These data are not consolidated. There is a need to expand the coverage of central government to include the complete transactions of the Social Security Organization, four pension funds, and five procurement and distribution centers.

- $\quad$ Since 2006, the data reported in the Government Finance Statistics Yearbook cover the general government sector.

- $\quad$ The existing cash-based government accounting system should be upgraded toward an accrual accounting system or a modified cash accounting where noncash operations (such as advances and arrears) are identified.

- $\quad$ Financing data in the GFS are broken down by residency of debt holders and by type of debt instruments according to GFSM 2001. However, there is a need to develop a 
comprehensive database on domestic and external public debt and to align the coverage of the monetary data with the coverage of the fiscal data.

- $\quad$ The target subsidy organization is considered as a public corporation and is classified in the nonfinancial public corporations sector.

\section{Monetary statistics}

- $\quad$ Monthly monetary data are reported to STA for publication in IFS, but periodicity has been lagging.

- $\quad$ Compilation of monetary statistics diverges from international standards in the application of the residency criterion and in sectorization and classification of accounts. The authorities are undertaking improvements in each of these areas, in line with the recommendations of STA missions.

- $\quad$ The measure of broad money employed by the CBI does not include deposits of public nonfinancial corporations, local governments, or foreign-currency deposits of residents.

\section{External sector data}

- $\quad$ The accounting system for foreign exchange receipts and payments of the CBI and banks is being implemented in line with the methodological guidelines of the Fund's Balance of Payments Manual, fifth edition (BPM5). This will allow compilation of balance of payments statistics on a quarterly basis. Annual balance of payments data up to 2000 have been reported to STA for publication in BOPSY and IFS.

- Data on the international investment position are compiled, but not disseminated. Only data on public and publicly guaranteed debt are disseminated, but classifications do not fully accord with the guidelines of the External Debt Guide. The data template on international reserves and foreign currency liquidity is not compiled. 


\section{Islamic Republic of Iran: Table of Common Indicators Required for Surveillance (As of June 15, 2011)}

\begin{tabular}{|c|c|c|c|c|c|}
\hline & $\begin{array}{l}\text { Date of latest } \\
\text { Observation }\end{array}$ & $\begin{array}{c}\text { Date } \\
\text { Received }\end{array}$ & $\begin{array}{c}\text { Frequency } \\
\text { of } \\
\text { Data }^{6}\end{array}$ & $\begin{array}{c}\text { Frequency } \\
\text { of } \\
\text { Reporting }^{6}\end{array}$ & $\begin{array}{c}\begin{array}{c}\text { Frequency } \\
\text { of }\end{array} \\
\text { Publication }\end{array}$ \\
\hline Exchange Rates & June 15, 2011 & $\begin{array}{l}\text { June } 15 \\
2011\end{array}$ & $\mathrm{D}$ & $\mathrm{D}$ & $\mathrm{D}$ \\
\hline $\begin{array}{l}\text { International Reserve Assets and Reserve Liabilities of } \\
\text { the Monetary Authorities } 1\end{array}$ & March 2011 & May 2011 & M & M & M \\
\hline Reserve/Base Money & March 2011 & May 2011 & M & M & M \\
\hline Broad Money & March 2011 & May 2011 & M & M & M \\
\hline Central Bank Balance Sheet & March 2011 & May 2011 & M & M & M \\
\hline Consolidated Balance Sheet of the Banking System & March 2011 & May 2011 & M & M & M \\
\hline Interest Rates ${ }^{2}$ & Dec 2010 & May 2011 & M & M & M \\
\hline Consumer Price Index & April 2011 & May 2011 & M & M & Q \\
\hline $\begin{array}{l}\text { Revenue, Expenditure, Balance and Composition of } \\
\text { Financing }{ }^{3} \text {-General Government }\end{array}$ & March 2011 & May 2011 & M & M & M \\
\hline $\begin{array}{l}\text { Revenue, Expenditure, Balance and Composition of } \\
\text { Financing }{ }^{3} \text {-Central Government }\end{array}$ & March 2011 & May 2011 & A & A & A \\
\hline $\begin{array}{l}\text { Stocks of Central Government and Central Government- } \\
\text { Guaranteed Debt }\end{array}$ & March 2011 & May 2011 & A & A & A \\
\hline External Current Account Balance & Dec 2010 & May 2011 & M & Q & Q \\
\hline Exports and Imports of Goods and Services & Dec 2010 & May 2011 & M & $\mathrm{Q}$ & $\mathrm{Q}$ \\
\hline GDP/GNP & March 2010 & June 2011 & Q & $\mathrm{Q}$ & $\mathrm{Q}$ \\
\hline Gross External Debt & Dec. 2010 & May 2011 & M & Q & Q \\
\hline International Investment Position 7/ & Sept. 2010 & May 2011 & A & I & NA \\
\hline
\end{tabular}

1/ Includes reserve assets pledged or otherwise encumbered as well as net derivative positions.

2/ Both market-based and officially determined, including discount rates, money market rates, rates on treasury bills, and notes and bonds.

3/ Foreign, domestic bank, and domestic nonbank financing.

4/ The general government consists of the central government (budgetary funds, extra budgetary funds, and social security funds) and state and

local governments.

5/ Including currency and maturity composition.

6/ Daily (D), weekly (W), monthly (M), quarterly (Q), annually (A), irregular (I), and not available (NA).

7/ Includes the external financial assets and liabilities vis-à-vis nonresidents of the financial sector. 


\section{INTERNATIONAL MONETARY FUND}

EXTERNAL

Public Information Notice

RELATIONS

DEPARTMENT

Public Information Notice (PIN) No. 11/107

FOR IMMEDIATE RELEASE

August 3, 2011
International Monetary Fund

$70019^{\text {th }}$ Street, NW

Washington, D. C. 20431 USA

\section{IMF Executive Board Concludes 2011 Article IV Consultation with the Islamic Republic of Iran}

On July 20, 2011, the Executive Board of the International Monetary Fund (IMF) concluded the Article IV consultation with the Islamic Republic of Iran. ${ }^{1}$

\section{Background}

Iran has started implementing a major subsidy reform by raising sharply the prices of energy and agricultural products in December 2010, removing close to US\$60 billion dollars (about 15 percent of GDP) in annual product subsidies. The subsidy reform is expected to increase efficiency and competitiveness of the economy, improve income distribution, reduce poverty, and help Iran unlock its full growth potential.

Economic growth rebounded from the cyclical downturn in 2008/09 to reach 3.2 percent for the 2010/11, spurred by a recovery in agriculture production, and higher oil prices. Building upon their success in reducing inflation from 25.4 percent in 2008/09 to 12.4 percent in 2010/11, the Central Bank of Iran was able to contain inflation in the aftermath of the subsidy reform. As a result, consumer price inflation has only increased from 10.1 percent in December to 14.2 percent at end-May 2011.

\footnotetext{
${ }^{1}$ Under Article IV of the IMF's Articles of Agreement, the IMF holds bilateral discussions with members, usually every year. A staff team visits the country, collects economic and financial information, and discusses with officials the country's economic developments and policies. On return to headquarters, the staff prepares a report, which forms the basis for discussion by the Executive Board. At the conclusion of the discussion, the Managing Director, as Chairman of the Board, summarizes the views of Executive Directors, and this summary is transmitted to the country's authorities. An explanation of any qualifiers used in summings up can be found here: http://www.imf.org/external/np/sec/misc/qualifiers.htm.
} 
Other key macroeconomic indicators continued to improve in 2010/11. The overall fiscal surplus is estimated at 1.7 percent of GDP in 2010/11, reflecting prudent spending policies. The current account surplus increased to 6 percent of GDP in 2010/11, in line with the recovery of oil prices.

While overall money growth had remained moderate, an increase in central bank credit to banks, mainly related to the financing of subsidized housing, led to the emergence of a wide spread between the interbank rate and the parallel rate, as well as a rapid increase in gold coin prices.

On the backdrop of high oil prices and expected efficiency gains resulting from the domestic subsidy reform, the outlook is positive with growth expected to rebound in the medium-term. Average inflation is expected to rise in 2011/12 because of a step increase in prices, but should come down in 2012/13 if the authorities implement sufficiently tight credit and fiscal policies. The fiscal balance and the current account surplus are projected to improve in line with the rise in oil prices in 2011/12.

\section{Executive Board Assessment}

Directors welcomed the economic recovery, the decline in inflation, and the improvement in the external and fiscal positions in 2010/11. Directors noted that the medium-term outlook remains positive on the strength of high oil prices and potential efficiency gains related to the recent subsidy reform. They stressed, however, that continued prudent policies are essential to maintain macroeconomic stability and lay the basis for sustained growth.

Directors welcomed the early success in the implementation of the subsidy reform, which is a critical step in enhancing energy efficiency, supporting growth, and moving further towards a market-based economy. Directors noted that cash transfers, financed out of the revenues arising from the energy price increases, were instrumental in supporting domestic demand, improving income distribution, and reducing poverty.

Directors stressed that tight fiscal and monetary policies are necessary to contain inflation and allow a smooth adjustment of relative prices following the subsidy reform. In particular, they encouraged the authorities to save any oil revenue windfall and sterilize the related foreign exchange inflows. They also emphasized that monetary policy should gear toward positive real rates of return and that central bank credit to banks should be restrained.

Directors noted the recent developments in the foreign exchange market and the authorities' commitment to a unified exchange rate. They encouraged the authorities to 
manage the exchange rate more flexibly and maintain a strong international reserve position.

Directors welcomed the authorities' efforts to strengthen the banking sector and agreed on the need to raise minimum capital adequacy and provision cover and put in place a comprehensive contingency preparedness framework. Directors noted that additional steps are needed to further reduce the large non-performing loan portfolio and that bank profitability would benefit from allowing banks more flexibility in setting rates of return and reducing operating costs. They supported the recent decision to increase the central bank's supervisory powers, but underscored that full autonomy would be necessary for the central bank to exercise its enforcement powers.

Directors welcomed the authorities' reform strategy based on privatization, a reduction of the role of the government, and market-based prices for energy and agricultural goods, with a view to achieving higher employment and growth. They considered it critical to restructure the enterprise sector through the adoption of energy-efficient technologies, while stressing the need to support the development of new growth sectors through labor market reforms, including adequate unemployment benefits. Directors also agreed that the full removal of subsidies and steadfast implementation of the ongoing tax and customs reforms are essential to further reduce Iran's dependency on oil and natural gas.

Directors noted the progress made in enhancing Iran's AML/CFT framework, and urged the authorities to step up efforts to bring the existing framework in line with international standards.

Many Directors noted the authorities' concern about the impact of sanctions on the transfer of oil export proceeds, including potential adverse effects on oil markets, and some Directors called on the staff to monitor and assess Iran's access to the international payment system.

Directors considered that economic data are broadly adequate for surveillance purposes, and encouraged the authorities to improve the timeliness of data provision. 
Public Information Notices (PINs) form part of the IMF's efforts to promote transparency of the IMF's views and analysis of economic developments and policies. With the consent of the country (or countries) concerned, PINs are issued after Executive Board discussions of Article IV consultations with member countries, of its surveillance of developments at the regional level, of post-program monitoring, and of ex post assessments of member countries with longer-term program engagements. PINs are also issued after Executive Board discussions of general policy matters, unless otherwise decided by the Executive Board in a particular case. The staff report (use the free Adobe Acrobat Reader to view this pdf file) for the 2011 Article IV Consultation with the Islamic Republic of Iran is also available. 
Islamic Republic of Iran: Selected Economic Indicators, 2008/09-2010/11

$2008 / 09 \quad 2009 / 10 \quad 2010 / 11 \quad 1 /$

Real GDP growth (factor cost; percentage change)

$\mathrm{CPI}$ inflation (period average; percentage change)

$\mathrm{CPI}$ inflation (end of period; percentage change)

Unemployment rate (in percent)

Central government balance (in percent of GDP)

Broad money growth (percentage change)

Current account balance (in percent of GDP)

$0.6 \quad 3.5$

3.2

$25.4 \quad 10.8 \quad 12.4$

$17.8 \quad 10.4 \quad 19.9$

$10.4 \quad 11.9$

$14.6 \quad 2 /$

$\begin{array}{lll}0.7 & 1.0 & 1.7\end{array}$

$15.2 \quad 23.5 \quad 26.7$

Gross international reserves (in billions of U.S. dollars)

$6.5 \quad 3.0$

6.0

$79.6 \quad 78.0 \quad 78.9$

Public and publicly guaranteed external debt (in percent of GDP)

$6.1 \quad 5.9$

5.4

Exchange rate (period average; rials per U.S. dollar)

$9,574 \quad 9,920$

10,339

Sources: Iranian authorities; and IMF staff estimates.

1/ Estimate.

2/ Data for the first quarter. 


\section{Statement by Jafar Mojarrad, Executive Director for the Islamic Republic of Iran July 20, 2011}

1. My authorities thank staff for an excellent set of papers and the constructive dialogue during the Article IV discussions. The authorities concur with staff assessment and policy recommendations. The discussions rightly focused on maintaining macroeconomic stability, sustaining high growth, and strengthening the financial sector. My authorities also wish to express their appreciation for the high-quality Fund technical assistance and advice.

\section{Economic Developments and Outlook}

2. Non-oil GDP growth picked up over the past two years, reflecting the global economic recovery, a strong rebound in agriculture production, and structural reforms. Despite the global recession and the economic sanctions, growth rates in recent years have been positive, but far below the potential of the Iranian economy. The authorities are mindful that reaching and sustaining higher growth rates would be vital for creating job opportunities for a growing labor force, particularly the youth. They are of the view that Iran's potential growth rate is much higher than that projected by staff, and envisage an annual growth rate of 8 percent over the period of the Fifth Five-Year Development Plan ( $5^{\text {th }}$ FYDP 2010-15).

3. Inflation has been brought down significantly from 25.4 percent in 2008/09 to 12.4 percent in 2010/11 through effective monetary policy. It is expected to increase to 22 percent in 2010/11 due to the step price increases stemming from the subsidy reform (see below), but to moderate to 7 percent over the medium term.

4. The current account surplus improved to 6 percent of GDP in 2010/11, up from 3 percent in 2009/10, reflecting higher oil prices and will remain in surplus over the medium term. The fiscal surplus increased from 0.7 percent of GDP in 2008/09 to 1.7 percent in 2010/11 due to the authorities' prudent spending policy as well as higher oil revenue. The fiscal balance is expected to remain in surplus over the medium term. 


\section{Subsidy Reform}

5. My authorities have carried out a comprehensive subsidy reform, which is one of the most important market reforms in 30 years. On December 19, 2010, the government ended the decades-long subsidy program for fuel and a broad range of other commodities, and replaced it with direct cash transfers to households of about US\$40 per month per person. The reform reduced the annual cost of subsidies on food, fuel, and electricity by US $\$ 60$ billion, about 15 percent of the GDP. Implementing a reform of such magnitude has required extensive preparations and planning, as outlined in the staff report and detailed in a staff working paper. ${ }^{10}$ The reform was preceded by a far-reaching public relations campaign to educate the population on the growing economic costs and environmental damage of low energy prices as well as the expected long-term benefits from the reform. Consumers were instructed on how to reduce wasteful use of energy and on the value of installing insulation, while industry was encouraged to improve energy efficiency and upgrade technology.

6. Broad consensus and extensive public support have been critical in the successful implementation of the first phase of the reform. This phase, which has entailed a substantial increase in energy products' prices, in some instances by up to twenty times, has been successfully implemented. Nevertheless, many challenges lie ahead, and with continued public support, the next phases of the reform are expected to be equally smooth.

7. The reform has slashed local energy demand, which has resulted in reducing chronic pollution and increasing available crude oil for export. It has dramatically raised disposable income of the poor, spreading social equity while boosting private non-energy consumption. Poverty incidence is estimated to have declined from 12 percent to 2 percent and regional disparities in poverty have sharply declined.

\section{Medium-and Long-Term Framework}

8. The authorities' objective over the medium to long term is to maintain macroeconomic stability, transition to a market economy, reduce the role of government, accelerate privatization of public enterprises, and reform labor and product markets. The policy framework for achieving these goals is laid out in the Twenty-Year Vision document and the $5^{\text {th }}$ FYDP, which seeks to achieve sustained annual economic growth rate of 8 percent on average and increase employment opportunities.

9. The objectives of the plan also include further economic diversification to substantially reduce the government's dependence on oil and gas revenues, elimination of subsidies, and a reduction in the gap between the rich and the poor and further protection of

\footnotetext{
${ }^{10}$ Guillaume, Dominique, Roman Zytek, and Mohamed Reza Farzin, 2011, "Iran—The Chronicles of the Subsidy Reform,” IMF Working Paper 11/167.
} 
the lower segments of society. Extension of health insurance and improvement of education and human development indicators are also among the key objectives of the Plan.

10. To further improve the business and investment environment and to reduce the cost of doing business, the Plan envisages the establishment of a "Dialogue Council" between the government and the private sector. The Council will be chaired by the Minister of Finance, with the participation of the Governor of the Central Bank of Iran (CBI) and seven ministers. In addition, the Organization for Foreign Investment and Technical Assistance of Iran will be further strengthened and the legal and economic environment for foreign direct investment will be improved.

11. In pursuing the objectives of the Plan, the authorities will continue to reform the financial sector as highlighted in the Selected Issues Paper (SIP). In the trade area, after carefully assessing the impact of the ongoing reforms, the authorities will proceed with further rationalizing the tariff structure and reducing the number of items that are exempt from import duties.

\section{Monetary and Exchange Rate Policies}

12. Maintaining price stability will be critical for achieving the Plan's growth and employment objectives as well as successfully completing the subsidy reform. The CBI will continue its efforts to reach a consensus in the Monetary and Credit Council (MCC) to increase the lending and deposit interest rates to contain credit growth and inflation. Also, the CBI will continue to tighten its lending to banks through the overdraft facility, and to mop up excess liquidity through the issuance of CBI participation paper.

13. As noted by the staff, the exchange rate is broadly in line with fundamentals and the managed float regime continues to serve the economy well. Going forward, the exchange rate will continue to be managed flexibly, taking into account monetary policy objectives, the need to maintain a unified exchange rate system, as well as developments in Iran's competitiveness.

\section{Fiscal Policy Reforms}

14. My authorities are well aware of the need to maintain fiscal sustainability over the medium term and reduce dependence on oil revenue. To this effect, they plan to strengthen revenue mobilization, rationalize current spending, and ensure high-quality capital expenditure. A key priority objective over the medium term is to ensure that non-oil revenue fully cover current expenditure. In this connection, the VAT rate will be increased annually by one percentage point over the next five years from its current rate of 3 percent. Moreover, to enhance compliance, an audit software will be implemented and a zero rate will be applied for all tax exemptions. To further strengthen fiscal buffers, 20 percent of oil revenue will be 
saved in the newly established National Development Fund while oil proceeds in excess of the budget price assumption will be channeled to the existing Oil Stabilization Fund.

\section{Financial Sector Reforms}

15. The authorities attach high importance to the soundness of the financial system, which is the world's largest Islamic financial system. With the privatization of four public banks over the past two years, the share of private banks in financial intermediation has increased significantly. The authorities intend to take measures, as needed, to ensure that financial institutions remain solvent and profitable. As underscored in the SIP, the CBI's regulatory and supervisory framework will be further strengthened and aligned with international best practices. As a first step toward developing a comprehensive contingency preparedness framework, a deposit guarantee fund will be established. The authorities agree with staff on the need for a higher minimum capital adequacy and stronger liquidity buffers. Under the $5^{\text {th }}$ FYDP reforms, public banks will be allowed to retain after-tax profits into capital upon government approval.

16. My authorities continue to strongly support international efforts in the area of antimoney laundering and combating the financing of terrorism (AML/CFT) and have made considerable efforts to fully implement the adopted measures. In their efforts to enhance the existing framework to meet international best practices, a Financial Intelligence Unit (FIU) was established on February7, 2010 and a draft CFT law, incorporating the Fund's Legal Department's recommendations is expected to be ratified soon by Parliament. In addition, the authorities have made extensive efforts to strengthen cooperation between Iran and other countries and international organizations actively involved in AML/CFT, including the FATF. Measures are also underway for Iran to gain membership in the Egmont group and regional FATFs. The authorities look forward to further IMF technical assistance to examine progress in developing the AML/CFT framework and the operation of the FIU and provide further recommendations while sharing the staff TA reports with the Board.

\section{Risk of Spillover of the Sanctions on Oil Markets}

17. As a large oil and gas exporter, Iran plays an important role in maintaining market stability. With its vast endowment in oil and gas resources, Iran has actual and potential capacity to support the global energy needs and meet the rising demand. However, my authorities consider that the imposition of unilateral and extraterritorial barriers for foreign investment in Iran's energy sector is counterproductive at a time when the world economy is confronted with supply scarcity. Of more concern are the recent difficulties created for the transfer of oil export proceeds to Iran by oil importers through the international payment and settlement system. Should these restrictions remain in place, Iran would have no choice but to cut oil and gas supplies to the interested parties, with possible spillovers to the energy markets. While my authorities remain committed to the integrity and effectiveness of the global financial and payment system, they believe that the Fund, as the guardian of global 
financial stability, has a role to play in ensuring the smooth functioning of the multilateral payment system for the benefit of the international community. My authorities are ready to provide management and Fund staff with all necessary information to allow the Fund to form a view on this issue and play a role in facilitating Iran's free access to the international payment and settlement system. 